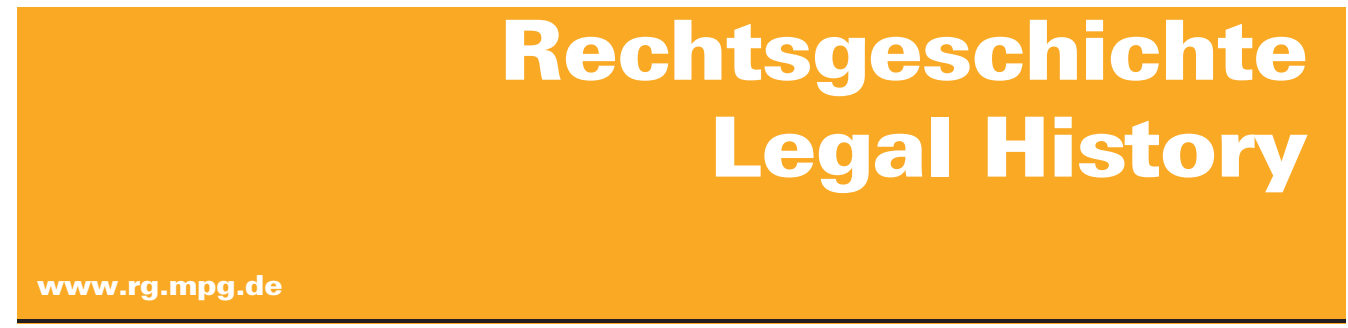

http://www.rg-rechtsgeschichte.de/rg23

$\operatorname{Rg} 232015 \quad 83-108$

Zitiervorschlag: Rechtsgeschichte - Legal History Rg 23 (2015)

http://dx.doi.org/10.12946/rg23/083-108

\title{
Luca Loschiavo
}

\section{Was Rome still a Centre of Legal Culture between the 6th and 8th Centuries?}

Chasing the Manuscripts 


\section{Abstract}

What happened to the tremendous legacy of juridical knowledge left behind in Italy in the $6^{\text {th }}$ century? Into what labyrinth did it plunge only to re-emerge after the silent age of the early Middle Ages into the light of day, and effectively come to shape the renewal of the jurisprudence at the beginning of the $12^{\text {th }}$ century? One-and-a-half centuries after the fanciful writings of Hermann Fitting, legal historians are still looking for the answers to these questions. Considering the new information we have (especially coming from the paleographical research), this paper re-examines the existence as well as the activities of the school of Rome both during the Justinian Age and in the two centuries thereafter. The aim of this essay is to verify whether Rome, during the very early Middle Ages, continued to represent a centre of juridical culture. According to the hypothesis developed in this contribution, Rome - at that time - not only played a very important role with regard to the material conservation of the Justinian's libri legales, but also in the initial establishment of the new (i.e., Justinian) imperial law in the West and creation of its image as a significant juridical centre. The absence of such a centre as well as its wide-spread image would truly make the Bolognese renovatio appear >miraculous and very difficult to explain.

After Justinian, the $7^{\text {th }}$ and $8^{\text {th }}$ centuries can truly be characterised as ssilent Roman law in the West. However, by studying the medieval manuscript tradition, in particular, that of the Institutiones and the Novellae, we can gather together a series of elements helping us to clarify the situation. Also quite useful is an examination of the manuscript tradition of the Collatio legum Mosaicarum et Romanarum. Through the spread and use of these Late Antique works, we can see how in conjunction with the actions of the papacy Rome, toward the end of the $8^{\text {th }}$ century, returned to being a centre of world politics and - given that law follows politics - of the legal culture. 


\title{
Luca Loschiavo
}

\section{Was Rome still a Centre of Legal Culture between the $6^{\text {th }}$ and $8^{\text {th }}$ Centuries?}

\author{
Chasing the Manuscripts
}

1 Odofredus and the somnia fittinghianar

$$
\begin{aligned}
& \text {... you have to know: at first the } \\
& \text { school was in Rome - so our } \\
& \text { ancestors tell us - afterwards, be- } \\
& \text { cause of wars in the marches, the } \\
& \text { school was destroyed. Then the } \\
& \text { school obtained a second seat in } \\
& \text { Italy, i. e., in the >Pentapolis } \text { which } \\
& \text { was later called Ravenna ... After } \\
& \text { Charles's death, the city collapsed, } \\
& \text { and then the school was brought } \\
& \text { to this city [i. e., Bologna] when } \\
& \text { the books [of Justinian] were } \\
& \text { brought here. }
\end{aligned}
$$

With these words, the Bolognese jurist Odofredus (around 1250) connected the origins of the School of Bologna to the ancient (imperial) school of law in Rome. For centuries (at least since Savigny), scholars have tried to verify the thesis by examining this and similar passages penned by Odofredus. ${ }^{1}$ If this contention could be substantiated, it would explain not only the smystery< surrounding the renewal of Roman law during the Middle Ages, but also the beginnings of modern legal science. Intrigued by these words, Hermann Fitting began developing - with as much erudition as fantasy - his thesis about the continuity of knowledge and use of Roman legal sources throughout the early Middle Ages. Starting in 1870, Fitting asserted that the activities of the school in Rome were never interrupted. According to this view, the school remained active until the $12^{\text {th }}$ century - effectively passing over the troublesome Lombard Age. This would also imply that several teachers of noteworthy status would have been active in the school at this time, among them the mysterious Geminianus, who, Fitting contends, must have taught the great Irnerius. In turn, after having concluded his studies in Rome, it is very likely, according to Fitting, that Irnerius himself started teaching at the school, and, quite possibly, he focused on the Justinian books. While lecturing at the law school, it is also possible that he wrote a series of influential works. Only as the Norman threat was approaching did he finally move to Bologna and thus the school of law with him. $^{2}$

At first, the continuity idea - contrary to Savigny's theory ${ }^{3}$ - was well-received, and, eventually, it became so entrenched that, for a while, some historians continued to defend it long after it had been called into question. In any case, scholars such as Jacques Flach, Max Conrat and Federico Patetta were soon able to dismantle large parts of Fitting's argumentation. When in the 1930s, Hermann Kantorowicz - referring to Fitting's theory adopted Mommsen's caustic tone regarding the somnia Fittinghiana, ${ }^{\mathbf{4}}$ it was as if a gravestone had been thrown at every survival hypothesis concerning the schools of law between the $6^{\text {th }}$ and the $11^{\text {th }}$ centuries. Even if today some scholars are struck by
1 Odofredus, In novem posteriores libros Infortiati (ad Dig. 35.2.82), ed. Lugduni 1550 [= Bologna 1968], fol. 83rb: "... maiores nostri ita referunt, debetis scire, studium fuit primo Rome postea, propter bella que fuerunt in marchia destructum est studium. Tunc in Italia secundum locum obtinebat Pentapolis, que dicta Ravenna postea ... Post mortem Karoli, civitas illa collapsa est, postmodum fuit translatum studium ad civitatem istam [i. e. Bologna], cum libri fuerunt portati«. Odofredus provides a simi- liar account (although without the same level of detail) when he remarks D. 1.1.6: »Signori ... cum studium esset destructum Rome, libri legales fuerunt deportati ad civitatem $\mathrm{Ra}$ venne et de Ravenna ad civitatem istam « (In Dig. Vet., de iustitia et iure, 1. ius civile, ed. Lugduni 1550 [= Bologna 1967], fol. 7rb). We notice here a recent tendency to reduce the meaning of Odofredus's account to an »identity-making myth «; see Ciaralli (2012), esp. 44 and bibliography quoted in fn. 3 and 4 ).
2 Fitting (1870) 97-99. Regarding the possible meaning of Irnerius's stay(s) in Rome, see Cortese (1993).

3 Kantorowicz (1912), esp. 436-438. See what F. C. von Savigny wrote, however, in SAvignY (1834) 476: »Es ist nämlich schon an sich sehr wahrscheinlich, daß die Rechtsschule zu Rom, die sich in Iustinianus Zeit findet, auch in der Folge fortgedauert hat."

4 Kantorowicz (1938) 145 (at fn. 1 the references to Mommsen) and 317 ad indicem. 
the remarkable similarities in the methods used by Byzantine legal practitioners and those employed by the Bolognese glossators, ${ }^{5}$ the idea that a continuity existed between the schools of Late Antiquity and those that flourished in the decades prior to Irnerius has all but been abandoned. ${ }^{6}$

And still, one-and-a-half centuries after Fitting's writings, historians are asking themselves what happened to this tremendous legacy in Italy. Into which labyrinth did this legal legacy descend only to re-emerge much later and set the stage for the renewal of medieval jurisprudence? ${ }^{7}$ In light of the information we now have access to, it would be interesting, once more, to investigate the existence and activities of the school in Rome during the Justinian Age as well as immediately thereafter. Furthermore, it would be interesting to verify whether or not Rome continued to represent a centre of juridical culture during the first centuries of the Middle Ages - to the extent such an expression could have been meant in that era.

The aim of this contribution is to verify the hypothesis that Rome played a very important role in the early Middle Ages as well. By »an important role«, I mean not only with regard to the material conservation of the normative texts (e.g., the libri legales to which Odofredus often referred), but also with regard to the establishment of the new imperial law in the West as well as an awareness of its significance. Without this establishment and awareness, the Bolognese renovatio really does appear quite miraculous and difficult to explain.
It should be emphasised from the very beginning that this path will be slow and laborious, paved with >ifs borderline hypotheses and deductions. Unfortunately, we do not have any real alternative. If we wish to know something about the end of imperial Rome as well as the beginnings of medieval Rome, given the absence of documents, we must content ourselves with conjecture and likelihoods. ${ }^{\mathbf{8}}$

2 Regarding the school of law in Rome in the $6^{\text {th }}$ century

What we know about the activities of this school is, indeed, very limited. Until the beginning of the $5^{\text {th }}$ century, the school was quite renowned and remained closely linked to the Roman Senatus. ${ }^{9}$ In light of Justinian's famous reference in the constitutio Omnem $(\$ 7)$, it was almost certainly in operation until the final years of the Ostrogothic Kingdom. In fact, in 533 (the same year Justinian published the Institutiones and Digesta) the young King, Athalaric, (under the influence of Cassiodorus) issued a decree in reply to the complaints of the local teachers of grammar, rhetoric and law concerning irregular payments. ${ }^{\mathbf{1 0}}$ This would seem to indicate that there was, at that time, at least one law professor at the school (nec non et iuris expositor). According to an intriguing hypothesis, this professor might very well have been Salaminius antecessor, i. e., the last one (and least well-known)
5 See, among others, Pringsheim (1921); Genzmer (1934), I, 365; Schulz (1953) 530: »the striking similarity of the scholia of the Basilica and the Bolognese glosses strongly suggests that Bolognese jurisprudence was influenced by Byzantine. But there is no evidence of this."

6 For a more general overview, see Astuti (1953); CoRtese (1995) 27-33; LANGE (1997) 1-23 and now LANDAU (2011), esp. 10-13.

7 So Nicolaj (2005) 767. See also SANTINI (1994), esp. 91: the Roman law revival and the origin of the school of Bologna remain a >miracles and a historiographical mystery.

8 This is how Marrou characterised it (1931) 169 (212 in Marrou [1978]). They were already recalled by $\mathrm{DE}$ Marini Avonzo (2007) 31.
9 Testimonies about the continuous existence of this school in the $6^{\text {th }}$ century - in particular concerning the legal teachings- are well-known. Among others, see Conrat (1907), 1, esp. 292-296); ERMini (1938); Volterra (1957), here 56. More recently, apart from Liebs (to whom we will eventually return), see DE Marini Avonzo (2007) and Di Paola (2007).

10 The epistola (Cassiodorus, Var., 9.21.5) was sent to the Senatus of Rome to be put into practise: public education in the City was evidently a duty of the Senatus; see Bertolini (1941) 11 and 109-110 and Di PaOla (2007) 93. 
of the eight professors to whom Justinian addressed the const. Omnem. ${ }^{\mathbf{1 1}}$

However, terrible and tumultuous times would soon visit the ancient capital: re-conquered by the empire in December 536, besieged in vain for an entire year by Vitige (537/538), and then forcefully taken by Totila in 546, Rome was, again, retaken (547), and then lost by the Byzantines (550), only to be definitively conquered in the summer of 552 . Nevertheless, even in the face of so much war and ruin, the continuation of at least some school activities in Rome - including the teaching of law - cannot be dismissed out of hand.

Perhaps when Constantinople, on the one hand, collaborated with the young Ostrogothic king of Ravenna, Athalaric, and, on the other, intensified its contact with the Roman Senatus and the Pope, Justinian had already sent copies of his law books to Ravenna and Rome to be studied and applied - patria legum, fons sacerdotii (Nov. 9, 535). ${ }^{\mathbf{1 2}}$ Another possibility is that they could have been sent in 537 (or immediately thereafter) once the praefectura praetorio was re-established in Italy. ${ }^{13}$ As we will see, there are reasons to believe that a professor, who taught the elementary text of the Institutes, might very well have arrived in Rome during the brief period of peace between 539 and 545.

Roughly twenty years later, however, the very same Justinian appears to have taken inspiration from the previously mentioned ruling of Athalaric, when he decreed the Pragmatica sanctio pro petitione Vigilii (554). Having definitively recaptured Italy, the emperor was now determined to demonstrate his will to restore the greatness of the new province after the mourning and ruin of the endless Gothic war. ${ }^{14}$ Justinian's aim was to re-establish the ancient school in Rome, so that it may serve his political project. ${ }^{15}$ If we are willing to believe that the intention behind the offering of courses on grammar, rhetoric and medicine was, generally speaking, to enrich the culture, the re-introduction of juridical instruction was principally aimed at forging new and trustworthy civil servants. ${ }^{\mathbf{1 6}}$ However, it is unclear whether Justinian's decree to resume teaching in Rome was ever realised. And even if we concede that the school was re-started in the months (or years) after the Pragmatica sanctio was issued, its subsequent operation in the years following remains unclear.
11 For the most part, he has been ignored within the research. In the const. Omnem, however, he is separately mentioned as the slast one and as possessing the lesser title of vir disertissimus (the others are named viri illustres). We can presume that he must have had an inferior sacademic role. The hypothesis that he might have been a teacher at the school in Rome was first (1934) suggested by Mor (see Mor [1977] 87) and considered plausible by M. Bellomo (1997) 43 as well. On the other hand, J.R. Martindale (1992) 1107, without introducing any new positive elements, prefers connecting Salaminius to the School of Beirut. P. Collinet (1925) 190 and 195 links him to Constantinople and excludes the hypothesis of him having taught in Rome on the basis of a reasoning perhaps too formal (with respect to the very particular institutional structure of the Ostrogothic Kingdom): »... il ne peut figurer dans cette liste aucun professeur de Rome, puisqu'en 533 Rome n'avait pas encore été reconquise par les armées de
Justinien« (see, however, the next footnote).

12 The order to send the books to Rome is actually contained in the paragraph previously mentioned from the const. 'Omnem. Cellurale (2011) has recently stressed the real legal unity existing between the Empire and the Ostgothic Realm. She argued that the pragmatic of 554, more than sextending the operative force of the new legislation, simply reasserted its validity. The sense of the Nov. 9 seems to exclude a circulation of the Justinian Code in Italy prior to 535 (Goria [1984] esp. 337). Actually, we should not forget that new Byzantine norms were introduced in Italy between 539 and 540, most certainly by 550 , and thus much earlier than the publication of the Pragmatica sanction; seeTJÄDER (1985), esp. 28, 31 and 33-34.

13 Pescani (1966) 554.

14 In the following passage, BERTOLINI (1941) 185, tries to sum up the probable mood of the inhabitants of Rome in those moments, who had in less than 16 years from the outbreak of the war between Goths and Byzantines experienced a great deal: »l'Urbe aveva subito quattro assedi; aveva visto furiose battaglie combattersi da stranieri sotto le sue mura; aveva sofferto fame e pestilenze. Ridotti a pochi i suoi abitanti; dispersa, decimata, colpita nei suoi affetti più cari l'aristocrazia senatoria; trattenuto a Bisanzio il suo Vescovo, Roma doveva domandarsi nel pianto se Giustiniano ed il suo luogotenente in Italia avrebbero medicato le piaghe di cui dolorava e quale sorte i conquistatori le riserbavano«.

15 Pragmatica sanctio, $\mathbb{\$} 22$ is surely to be seen in connection with the preceding $\ 11$ of the same Pragmatica and with $\$ \int 6$ and 7 of the const. >Omnem<; see Archi (1981c), esp. 1987-1998 and 2008-2009, and now Cellurale (2011) 23-24 and 28-30.

16 See Archi (1981b), esp. 1938. 


\section{Liebs's Contribution}

Most recently, and above all, Detlef Liebs has been researching the law school in Rome during Justinian's reign as well as in the years immediately following. ${ }^{17}$ By adding new arguments to those used by Fitting - and not refuted by other scholars - Liebs tries to connect several of the remaining testimonies of jurisprudence from that period to the school in Rome.

The commentary to the Institutes, from which the ancient nucleus of the so-called Turin gloss derives (ms. Torino, Bibl. Naz. Univ., D.III.13), could have been composed in Rome (or simply used by an antecessor originally coming from the East) sometime during the ongoing Byzantine reconquest ${ }^{18}$ between 542 and $545 .{ }^{19}$ Despite having been altered and reworked (Liebs contends that the remnants of the ancient glosses we currently have represent a transcription made by a sicht Jurist < a few centuries later), ${ }^{\mathbf{2 0}}$ the document we currently have in our possession is supposed to represent the unitary work of a teacher lecturing to Latin-speaking students. The teacher, as his own words indicate, was operating in Rome. He almost certainly used the Paraphrasis to the Institutes of Theophi$\operatorname{los}^{21}$ together with the Code, the Digest, the Quinquaginta decisiones and one peculiar (and unknown) collection of Justinian's Novellae. ${ }^{\mathbf{2 2}}$

The Latin paratitla to the Epitome Iuliani, composed just a few years later, are also connected to the Roman school. These notes were meant to serve both as a companion to the text as well as integrate the lecture dealing with the Epitome in order to point out the connections to other norms contained in Justinian's law books (require legem ...). Moreover, they often served to highlight the normative innovations introduced by the new impe- rial constitutions (hoc innovatum est ...). The paràtitla clearly derives from the aforementioned teachings, and they were most likely composed between 557 and $565 .^{23}$ Liebs primarily focuses on the low quality of the commentary concerning Iulianus's work. In his view, the text is supposed to be the product of an antecessor active in the Roman school while Justinian was still alive. ${ }^{\mathbf{2 4}}$ The paràtitla, in particular, derived from a course treating the Novels; the teaching method used corresponds perfectly to the method utilised by the antecessores. ${ }^{25}$ The teacher would have utilised: a) an index (the Epitome of Iulianus), b) a collection of Novels in their integral text (rethòn) and c) a word-for-word Latin translation (kata poda) in addition to the Greek texts (or at least a majority of them).

Liebs, drawing on one of Scheltema's hypotheses, believes that the Latin kata poda (interlineated in the original text) could have been the predecessor to the Authenticum used by medieval glossators. Moreover, the Authenticum itself (in its original version) is said to be a product of the school in Rome, and it is derived from a course treating the Novels held sometime between 557 and 559. ${ }^{\mathbf{2 6}}$

According to Liebs, at the end of the $6^{\text {th }}$ century (a few decades after Justinian's death), other works appeared from the Roman school. Of particular interest are the short and elementary summaries (summae) of individual chapters of the Epitome Iuliani found in some manuscripts and edited by Hänel under the title »summaria capitum «. ${ }^{27}$

Finally, Liebs identifies what he considers to be the last truly important testimony of legal teachings in Rome: the so-called Summa Perusina (alias Adnotationes codicum domini Iustiniani). This text which shows obvious similarities to the previously mentioned summaria of the Epitome Iuliani - could very well be the result of a series of lessons held on
17 LiEBs (1987), esp. 124-129, 195-220 and 246-282 and, more synthetically, LiEBS (2000) 253 and 256-257.

18 LiEBs (1987) 195-220 (esp. 202-208). The so-called Turin gloss has been edited more than once: from SAVIGNY (1834) 429-476 [in his Italian version SAVIGNY (1857) 107-150, E. Bollati expanded that edition]; from P. Krüger (1868); and from A. Alberti (1933). The literature is ample: it was recalled and discussed by the same Liebs, who, moreover (196, fn. 14), indicates the presence of a transcription of the gloss made sex novo by
Max Conrat (Institute for Legal History at the Freiburg University) at a time when the Turin manuscript had not yet been damaged by a fire in 1904 [see also Kantorowicz (1912) 481 sub XLV].

19 LiEBS (1987) 202-204, in fact, repeats the date proposed by Fitring (1870) 5-8 (between 543 and 546), but he supports it with new arguments. See, however, Besta (1923) 111-112. 20 Liebs (1987) 199.

21 The likely derivation of the Turin gloss from Theofilus's Paraphrasis a question already widely discussed within the historiography by Krüger and Ferrini as well as later by Liebs has recently been argued for by

G. FALCone (1996) as well (v. infra, fn. 33). Concerning the important Byzantine commentary (dating to $533 / 534$ ), it is now available in a modern and excellent edition by Lokin et al. (2010).

22 LiEBS (1987) 202-203.

23 Liebs (1987) 259.

24 Liebs (1987) 263.

25 See Scheltema (1970).

26 LiEBS (1987) 266-269.

27 LieBs (1987) 269-273. 
the Codex Iustinianus around 620/630. After this point in time, Liebs contends - and here he distances himself from Fitting's >continuity< theory that the teaching activities at the law school in Rome came to an end. Yet, Liebs's efforts to provide a substantial and realistic account of the teaching activities at the law school in Rome during this troubled period have met with scepticism. ${ }^{28}$

\section{Traces of a course on Justinian's Institutes}

Charles Radding and Antonio Ciaralli, in their recent and influential book on the transmission of the Corpus Iuris Civilis from Late Antiquity to the medieval juridical revival, are quite critical of Liebs's hypothesis concerning the Turin gloss. ${ }^{29}$ First of all, they stressed how the drafting of the Turin manuscript has to be post-dated to the late $11^{\text {th }}$ century. ${ }^{30}$ They also raise several objections to Liebs's arguments and conclude that »the ancient materials in the Turin glosses are too limited and uncertain to demonstrate the existence of a $6^{\text {th }}$ century law school in Rome«. Contrary to Liebs's position, Radding and Ciaralli argue that such ancient material shows the spioneering « way in which Justinian's books were making a comeback and were being copied and read with renewed interest toward the end of the $11^{\text {th }}$ century. ${ }^{31}$

However, the arguments proposed by the two scholars are not as conclusive as one might think. ${ }^{32}$ A number of elements that should have been included in the analysis were not taken into account. For instance, it was not all that long ago that Giuseppe Falcone took very seriously the idea that a consistent number of these ancient Turin glosses were actually the work of a teacher from the Late Antiquity, who used Teophilus's commentary
28 SANTini (1994) 135 and passim. While Santini considers the continuity of juristic teachings in Rome (and in Ravenna) between the $6^{\text {th }}$ and $7^{\text {th }}$ centuries to be very probable, he completely ignores, like many others Italian scholars of the medieval legal tradition, the works of Liebs.

29 Radding / Ciaralli (2007) 112-118.

30 Radding / Ciaralli (2007) 9 and 113. For quite some time, the relevant opinions fluctuated between the $9^{\text {th }}$ and $10^{\text {th }}$ centuries. However, already in 1948, Guiscardo Moschetti placed it around the $11^{\text {th }}$ century (Moschetti [1953] 504). Recently, F. MAcino (2008) revisited the code (47-48 and 68-73): in addition to reaffirming the $11^{\text {th }}$ century, she also locates the origin of the copy of the ancient part of the code somewhere in central Italy (perhaps in Tuscany).

31 Radding/Ciaralli (2007) 118.

32 Radding/Ciaralli (2007) note in primis (a) that "the author of the glosses apparently returned more than once in his script «, and, for that reason (according to them), he "cannot have been ... simply reproducing glosses from a single pre-existing work but rather was a scholar collecting materials from multiple sources and perhaps adding some of his own (114). Then, (b) they stress that the Turin glosses supposedly belonging to the oldest nucleus occasionally stem from different people (and previous editors made more than one error). In conclusion, they suggest going back to the manuscript itself (115). It should not be forgotten, however, that the manuscript was seriously damaged by fire in 1904 (sup$r a$, fn. 18), and that the text the first editors had was actually easier to read. Radding and Ciaralli also think that (c) if the manuscript was not drafted in the $10^{\text {th }}$ century - as Liebs believes - but at the end of the $11^{\text {th }}$ century, transcribing glosses could not have been the job of a non-jurist (115). That last argument is really based on the assumption - disputable in itself that, around the late $11^{\text {th }}$ century, only a jurist $<$ could be interested in doing gloss transcriptions. On the contrary, we know that, among the persons who first took up the Justinian's laws with renewed interest, there were surely some magistri of liberal arts for whom the rhetoricgrammatical profile could be more interesting than the purely juridical aspects. In every case, according to those scholars, (d) the uncertain and mistake riddled language of the glossator, which Liebs always emphasised, is instead »the normal Latin for $11^{\text {th }}$ century Italians « (116). We all know that Late Antiquity and Medieval Latin were in such disarray that any and every theory could be made to accord with it. Moreover, they consider very important (e) a few similarities between the ancient Turin glosses, for instance, those of the Cologne manuscript and those we find in the Walcausina (e.g., an incorrect interpretation by the Turin glossator). For them, these similarities must mean that they originated from the same centre, i. e., the Lombard school of Pavia (117). Also, without going into the criticisms recently raised concerning the Lombard origin of the Cologne glosses (126-128, see here LANDAu [2011] 14-22, and FeENSTRA [2011]), those correspondences do not prove a genuine derivation of the ancient Turin glosses from Lombard jurisprudence, but only serve to demonstrate a relationship between them (thus, also rendering the opposite hypothesis plausible). Finally, according to them, (f) the same gloss in which we find the Iliad cited in the Latin version of Silius Italicus should be placed in the $11^{\text {th }}$ century (117). Insisting on themes taken from the Homeric tradition might instead point to rhetorical literature of the $6^{\text {th }}$ century as the origin (as proved, for example, in Ennodius's works; see ERMINI (1938) $56-57$, who evokes, in particular, the Dictiones XXV-XXVIII). 
(with a few >improvements $<$ ) to explain Justinian's Institutes to his students. ${ }^{33}$ Even if we set aside the conclusions of the legal historiography comparing the most ancient Institutes manuscripts, ${ }^{\mathbf{3 4}}$ one simply cannot ignore the interesting evidence emerging from investigations of the manuscript tradition concerning precisely this Justinian law book.

5 Manuscripts of the Institutes and both their archetypes and ancestors

First of all, it should be pointed out that the well-known code Jur. 1 (antea D.II.3) in the holdings of the Bayerische Staatsbibliothek in Bamberg, as even Radding and Ciaralli confirm, originated in Rome. Recently re-dated to the end of the $10^{\text {th }}$ century $^{35}$ or, more probably, the beginning of the $11^{\text {th }},{ }^{36}$ the Bamberg code remains »the earliest intact manuscript of the Institutes «. ${ }^{37}$ Henry II could have acquired the manuscript in Rome and brought it with him back to Germany. ${ }^{38}$ We can safely assume that this version already had a number of glosses written in the margins by one or more scribes prior to its travels. Some of these glosses - just like the Turin glosses - seem to de- rive from models utilised in the Justinian Age. ${ }^{39}$ One gloss in particular, it seems, might very well derive directly from Theophilus's Paraphrasis. ${ }^{\mathbf{4 0}}$ Indeed, more or less, the same gloss also appears in the Turin manuscript. However, the gloss appears in a different place within the document, and the formulation of the text has been slightly altered; therefore, closing off the possibility of a direct textual lineage. If we let our imaginations run a little wild, perhaps we would hit upon the idea that both commentaries are actually notes taken during the lessons by different students. Such a possibility would resonate more clearly with the activities of a productive and functional school than being the result of mere copy work.

The Roman origin of the Bamberg code is, moreover, noteworthy for another interesting reason. If we consider its textual variants, the code is closely related to a series of other important manuscripts of the Institutes; the most ancient of these manuscripts is known today as ms. XXXVIII (36) of the Biblioteca Capitolare in Verona.

Today, no more than three palimpsest folios remain of that ancient manuscript in uncial, and which are attributed to the end of the $6^{\text {th }}$ or beginning of the $7^{\text {th }}$ centuries. ${ }^{41}$ Perhaps having just arrived in Verona sometime in the $9^{\text {th }}$ century, the
33 After a meticulous examination of ca. 70 glosses, whose source of derivation different scholars in the past attributed to the work of the Byzantine antecessor, FALCONE (1996) 257 concluded that - once rejected those »il cui preteso rapporto ... o appare assolutamente ingiustificato o non è sorretto da elementi di qualche peso «it remains a nucleus of, more or less, thirty glosses for which »la derivazione dallo scritto bizantino [può] ritenersi certa ... o estremamente verosimile $«$.

34 Both Patetta (1967b) 81-82 and Alberti (1935) 99-106 were convinced that the Turin manuscript including its ancient part - would have remained in the Latium till recent times. Moreover, according to Alberti, »la glossa di Colonia ebbe origine in un luogo del tutto diverso da quello nel quale originò la Glossa Torinese ...«(102).

35 Supino Martini (1987) 127-128.

36 This was related by Armando Petrucci in an oral communication reported by Ciaralli (2002), esp. 78 fn. 16 and 81. The mention of a volume Iustiniani de legibus in the catalogue of S. Michaels monastery's Library (ca. 1112-1123) allows us to speculate about the presence of the Institution manuscript already at the beginning of the $12^{\text {th }}$ century; see BECKER (1885), nr. 80, p. 104.

37 According to Radding / Ciaralli (2007) 70; however, even Patetta mentions this much earlier in Contributi (Patetta [1967b] 136). About the manuscript and the discussions it triggered, see Ciaralli (2002) 78-82 and Macino (2008) 64-68.

38 Bischoff (1984), esp. 176. Bischoff revives the hypothesis developed by P. E. Schramm (1929), esp. 199, and (1992) 277-278, according to whom, Otto III would have brought the manuscript with him across the Alps.

39 Conrat (1884) xlvi-xlviii, ccli-cclv (ed. on p. xlvii) and (1891) 118-119, 163-165, and Pieler (1978) 421 and, for the palaeographic aspects, Ciaralli (2002) 82-83.
40 Ed. in Conrat (1891) 119 fn. 1. Two other glosses from the Late Antiquity with excerpta from the Digest (a couple of definitions taken up respectively from D. 11.7.2.4 and 5) have been edited and discussed by Conrat (1884) xlvii. Ciaralli (2002) 82-83 indicates the presence of reproduced Code in the margins of passages (C. 1.1.17).

41 Recent descriptions of the fragment can be found in KaISER (2004) 406-410 and Macino (2008) 29 (where the precedent literature can also be found). 
code was destroyed to obtain parchment for reuse. However, an integral copy was made before being serased . Evidently, the aim of this recycling programme was to replace an old text of the Institutes with a new one; a version drafted in a >modern $<$ and more accessible writing. Later, however, the new copy shared the same fate as its predecessor and was eventually dismembered. A number of fragments remain scattered between Verona (mss. Bibl. capitolare, CLXXIII ${ }^{\mathrm{A}}$ and Bibl. civica, 3035) and New Haven (Yale Univ., Beinecke Library, Ms. 744). All of the fragments have subsequently been examined and edited by Guiscardo and Cesare Moschetti. ${ }^{\mathbf{4 2}}$

The meticulous examination of those fragments (both in Verona and in New Haven) reveals that they "adhere to the Bamberg code in a more narrow and unquestionable kinship «. ${ }^{43}$ We can easily suppose that such a kinship also extends to its $6^{\text {th }}$ or $7^{\text {th }}$ century predecessor. If this is, indeed, the case, then it would not be difficult to imagine that this uncial manuscript and Bamberg code shared a common archetype, and that it was sent from Rome to the scriptorium of Saint Zeno in Verona. $^{\mathbf{4 4}}$

The same Bamberg manuscript might then have an ancestor in common with the code from which the famous Berlin fascicle (containing the ending paragraphs of the Institutes and the beginning paragraphs of the Digest) was copied (ms. Berlin, SBPK, lat. fol. 269). ${ }^{45}$ According to Patetta, this fascicle could have shared an archetype originating from Byzantine Italy. ${ }^{46}$ The kinship between both manuscripts of the Institutes text, the Bamberg and the Berlin codes, seems to support and validate just such a conclusion. We will come back to the Berlin code later in this analysis.

One can clearly see the close relationship between the Bamberg manuscript and a third ancient testimony of the Justinian Institutes: the code utilised by the author of the collection of Gothic and Roman rules known as Collectio Gaudenziana. Our knowledge of this collection is derived from a single manuscript dating back to the end of the $10^{\text {th }}$ or beginning of the $11^{\text {th }}$ century (ms. London, British Library, Add. 47676). According to Wolfgang Kaiser - who conducted an extensive and meticulous examination of the Collectio - it could have been assembled at the same time as the manuscript itself. ${ }^{47}$ Almost certainly the collection was assembled in Southern Italy. Yet, it is precisely this kinship with the Bamberg code ${ }^{\mathbf{4 8}}$ that points in another direction; namely, that the author copied the excerpta of the Institutes from an antigraph stemming from Rome. ${ }^{49}$ The idea of a common
42 Moschetti (2006). Concluded, yet left unpublished by the father, the work on the Verona fragments was edited by his son, Cesare, who, moreover, added the edition of the new American fragments. See also Macino (2008) 20.

43 These words stem from the notes left by G. Moschetti (see the Premessa in Moschetti [2006] 5). They are confirmed by the critical footnotes to the edition (51-107): the variants common to $B$ (= Bamberg, SB, Jur. 1) are surely much more substantial than to any other manuscript.

44 Perhaps at the request of the archdeacon Pacificus with precisely the intention of staking and preservings, especially with regard to important writings of Roman heritage considered - as correctly emphasised functional to the cultural action supported, in particular, by some Italian ecclesiastical circle in the Carolingian era; see Macino (2008) 16-17, who contends the antigraphs stem from Verona and Ravenna (where she thinks a school of law existed), yet not from Rome.

45 Patetta (1967b) 154 fn. e. Even if only in an indirect way, the relationship between the two manuscripts might be confirmed by a style remark: the peculiarity of a gloss which should have been in the margins of the manuscript from which they were copied, i. e., the famous initial passages of the Digest in the Berlin code; see KaISER (2004) 413 fn. 77, 701, and here, infra, p. 98-99.

46 Patetta (1967b) 151.

47 KaISER (2004) 655-846 (where the manuscript is often referred to by the incorrect number 46676). RADDING / Ciaralli (2007) 70-72 also agree with Kaiser's conclusions. The London code has more recently been slightly post-dated (with respect to the dating suggested by Lowe and accepted in general) by Macino (2008) 42-44 and 54-58.

48 According to KaISER (2004) 695-703, esp. 696: "Even though many titles of the Institutes are lacking in the Col- lectio Gaudenziana and the present text is actually much re-elaborated, there are many errores coniunctivi that lead us to conclude that a closer kinship exists between the Collectio Gaudenziana and the ms. Bamberg, Bay. Staatsbibl. Jur. 1«.

49 Also pointing in this direction is the presence of quotations from book XI of the Codex (C. 11.48) with complete inscriptions; see KaISER (2004) 703-705. More or less in the same timeframe, an unknown glossator copied some constitutions taken from the same title of the Code in the margins of the book V (De legibus) of the Etymologiae/Etymologies of Isidore of Siville; see A. Bellettini (2009), esp. 37-38 and 45-47. See also infra fn. 132 . 
originating context or centre becomes all the more probable if we consider the similarity that this predecessor seems to have with the Late Antique manuscript from which the final passages of the Institutes in the Berlin fascicle were copied. ${ }^{50}$

It was correctly observed that the most ancient manuscripts of the Institutes show definite signs of contamination. ${ }^{51}$ Such a contamination must have already taken place at a very early point in the long history and transmission of the text. It is much easier to envision such a situation arising within the context of a centre, where a number of Institutes testimonies would all have been present at the same time. On the other hand, we have seen how the Bamberg (Jur. 1), Berlin (lat. fol. 269), London (Add. 47676) and Verona (XXXVIII [36]) manuscripts represent as many probable or possible testimonies (albeit indirectly) to the presence of one or more Institutes codes in Rome belonging to the Justinian era. It is sufficient to simply suppose that such a centre had to be located in the ancient capital.

We should not forget, however, that a similar contamination seems to have affected not only the normative text but also a number of glosses, including those stemming from teachings of the Late Antiquity. ${ }^{52}$ While by no means a proven fact, the hypothesis that the same centre - during Justinian rule - was also the venue for teachings of the Institutes, nevertheless, remains plausible.

6 Teaching of the Novels according to the method of the rantecessores

Of course, it is much too early in the analysis to jump to any conclusions. Yet, at the same time, it appears equally premature to reject Liebs's hypoth- esis, as Radding and Ciaralli do, concerning the possible derivation of the (ancient nucleus of the) Turin gloss from a Roman teaching of the Institutes at this point. ${ }^{53}$ Perhaps the insufficient consideration Radding and Ciaralli give to the existing traces of legal teaching in Rome during the $6^{\text {th }}$ century stems from a - more or less unconscious form of conditioning, the result of which lead to the exclusion of the tradition tied to Justinian's last legislation during the early Middle Ages. While their selection of materials is not without its reasons, ${ }^{54}$ it prevented them from taking a broader and more complex framework into consideration; for the last legislation of the Byzantine emperor is, in fact, the part of Justinian law that was most widely circulated throughout the early Middle Ages (both in Italy and beyond).

It has already been mentioned that Liebs claimed to have recognised new testimonies concerning the juridical teaching in Rome by examining the different materials deriving from a course on the Novels; a course held while Justinian was still alive. First, the Latin paratitla to the Epitome Iuliani were analysed. In his important study on the Epitome, Kaiser devotes a great deal of attention to these notes and cross-references (Querverweise). He shows how these paratitla belong to a much broader and varied manuscript tradition than previously thought. ${ }^{55}$ Other than in the Wien (ÖNB, lat. 2160; IX ex.) and Leipzig (UB, Hänel 6; antea 3503; XI.3/4) manuscripts (from which they were edited - first by Hänel ${ }^{56}$ and later (and certainly better) respectively by van der $\mathrm{Wal}^{57}$ and Liebs ${ }^{58}$ ), we also find the paratitla in other manuscripts of the Epitome. Apart from a few differences that can be explained when given the manuscript tradition, the kinship between the various testimonies is quite clear. Kaiser is in agreement with Liebs
50 Together with the Lex Romana canonice compta (or Capitula legis Romanae), the Collectio Gaudenziana and the gathering of the ms. Berlin, lat. fol. 269 , are, in fact, the sole testimonies of a very peculiar closing formula added to the Institutes; see KAISER (2004) 406-409.

51 KaISER (2004) 699-700.

52 See, for instance, Alberti (1935) 99-106.

53 Considering what we noticed above, what RadDing / Ciaralli (2007) 38 wrote right above Liebs's thesis, for instance, is not particularly convincing: "No contemporary source mentions a law school in Italy« and "Nor ... does the surviving manuscript evidence suggest any broad diffusion of the Institutes in Italy, even though that work was prepared specifically for use in law schools". One is left wondering what they considered the rulings of Athalaric and Justinian to represent?

54 Radding / Ciaralli (2007) 32-33: "Not only has the Epitome Iuliani recently been the subject of a detailed monograph by Wolfgang Kaiser, but its history in the early Middle Ages was ... very different from that of the rest of the Corpus."

55 KAISER (2004) 281-307 and passim.

56 HäNel (ed.) (1873) L-LI (ed. 202208).

57 VAN DER WAL (1985) (ed. 102-37).

58 Liebs (1987) 246-264 (ed. 257-259). 
concerning both their date of composition (between 557 and 565) and that they were somehow related to the activities of the school. However, he remains doubtful as to their possible Western origins. Instead, Kaiser thinks that they are the product of an Eastern school, where lessons were also held on the Novels for Latin-speaking students. $^{59}$

It is very likely - almost certain - that teachers at the law school in Constantinople, even after the reconquest of Italy, continued to organise courses for people coming from the West (similar to those held by the antecessor Julian, perhaps starting from about 548). ${ }^{60}$ And just as in Julian's time, the new teachers responsible for organising the courses were also confronted with the problem of their students' insufficient knowledge of Greek.

Given such a difficulty - according to Scheltema's theory - the teacher needed an articulated series of didactic materials for these courses such as: (a) a Latin index; (b) a collection of the Novels in the original language and integral texts; (c) an inverted kata poda (i. e., from Greek to Latin) to be inserted between the lines of the Greek texts (the majority) and (d) a specific set of learning tools for Latin paragraphài and paràtitla. ${ }^{\mathbf{6 1}}$

The hypothesis of the Dutch scholar appears to be supported by the, more or less, consistent traces of related materials currently known. Indeed, we have the Epitome Iuliani, which was undoubtedly originally written as an Index and updated more than once. We also have the paratitla, which we are currently discussing. Finally, we are aware of more than one collection of Novels with integral texts. ${ }^{\mathbf{6 2}}$ Among these collections, we also have the Authenticum, which, in its primitive form, is most likely the result of the simple merging of the original texts of the Latin constitutions with the kata poda translations made from the Greek texts. ${ }^{63}$

Scheltema and Kaiser (albeit more recently) both think that such courses could only have been held at the law school in Constantinople. Nevertheless, there is reason to think that a legal teaching of this sort could also have existed in the West and, more precisely, in Rome.

\section{From Constantinople to Rome}

While Scheltema and Kaiser were probably right to think that the initial editing of the paràtitla was a product related to the school in Constantinople, it is, nevertheless, useful to focus our attention just a little longer on these cross-references in the Epitome Iuliani. Since we are now aware of their likely connection to the law school, it is time to focus on their manuscript tradition. Among the new testimonies mentioned by Kaiser, we also find the Berlin manuscript, SBPK, lat. fol. $269 .{ }^{64}$ Together with a few other items, in fact, it contains one of the oldest and most interesting testimonies of the Epitome Iuliani. The paratitla are attested to twice in the manuscript: the first time in the list of rubricae capitulorum preceding the Epitome; the second time in their usual position, i.e., in the margins of the Epitome itself. Kaiser was able to show how the paratitla of the text and those inserted into the list of rubricae form a unity: they represent two expressions of the very same teaching activity. ${ }^{65}$ At the same time, they reveal a comparison the author made with a collection of integral texts of Justinian Novels (alius codex) in which we can recognise the primitive version of our Authenticum. ${ }^{66}$
59 KAISER (2004) 301-307.

60 We can, indeed, assume that - at Constantinople - the Epitome Iuliani was integrated and later used by other professors till the time of Tiberius II. These new antecessores probably composed the rubricae and the paratitla to the Epitome; see KAISER (2004) 179, 214-227 and 281-307 (at 318-319 the hypothetical common use of the Epitome Iuliani and the Syntagma of Atanasius of Emesa). Here, we have to remember Scheltema (1970) 48-49, who thought that, from a certain point onwards, Byzantine schools had begun to direct an additional (and sixth) year of teaching specifically dedicated to the study of the Novels. The hypothesis seemed noteworthy to Pieler (1978) 425.

61 Scheltema (1970) 17-22 (= 71-74 [2004]).

62 We know of various collections that did not survive, but which were certainly used for teaching; see PIELER (1978) 409-411, 425-426 and 436-438 and Goria (2007). See also KaISER (2004) 353 and 360.

63 In addition to SCHeltema (1970)

52-57, see also KaISER (2004) 315-318, who signals the presence of paràtitla to the Authenticum of the ms.
Wien ÖNB lat. 2130: these paràtitla (to the Authenticum and, therefore, not to the Epitome) retain traces of the original (Greek) numbering of the Novels and could have been left in the Latin kata poda once separated from the original Greek text.

64 KAISER (2004) 287-299.

65 LiEbs (1987) 206 is of a different opinion.

66 KAISER (2004) 289-290, 294-295, 296-298. 
In a similar list of rubrics found within a code of the Spanish monastery of S. Lorenzo de El Escorial (ms. S.I.9; sec. XII me.), we can identify a new testimony of the same paratitla. ${ }^{67}$ This list shows a clear and close connection to the Berlin manuscript. ${ }^{68}$ Moreover, it is evidence that the comparison (which was only slightly apparent in the Berlin code) involved the Epitome Iuliani and the collection from which the Authenticum derives. The close relationship between the two collections, which perfectly matches the teaching methods of the Byzantine antecessores, is, furthermore, confirmed by an ancient scholion well-known to the scholars, and which the Spanish manuscript now offers in a more complete and comprehensible version. $^{69}$

The textual proximity between the lists of Escorial and Berlin involves not only the rubrics, but also the paratitla contained therein. The relationship even becomes a true kinship. ${ }^{70}$ At the same time, the common variants distinguish the Escorial and Berlin paratitla from those of the Wien and Leipzig manuscripts. Such a rich and complex tradition - as already correctly noted - can only be explained if the different ancestors were produced in the same context and with the same aim. ${ }^{71}$ Given that the only solid evidence for this variation stems from the Western manuscript tradition, makes it even more difficult to believe that the different ancestors of these Latin paratitla were all imported from the East. (In this case, we should suppose the arrival in the western regions of more >originals independently of one another).

What if the different transcriptions were made by students attending the same course held in the West by a teacher using school materials he brought with him from Constantinople? The fact that in Constantinople there were courses on the Novels for Latin-speaking students does not exclude the possibility that a similar course - once held in the Byzantine capital - could also have been later repeated (perhaps multiple times) in Italy, specifically in that school in Rome to which Justinian wished to breathe new life. What prevents us from imagining that, after having taught in the Eastern capital, the same antecessor (or perhaps a former pupil) brought all the necessary materials with him to Rome with the explicit purpose of reusing them (perhaps even reworking and enhancing the materials)? In such a case, the teacher would have first used an updated collection of Novels (the complete text) brought with him from Constantinople. Regarding the constitutions written in Greek, he could have provided his students with the appropriate resources and learning tools. Perhaps he brought the apposite kata podas with him, or he wanted to (once in Italy) compose some of them himself, and that he also used Latin translations of individual Novels already available.
67 Loschiavo (2010), esp. 121-134 and 147-149.

68 In this sense, militate both the characteristic start (see KAISER [2004] 174) and, especially, the headings that are often corresponding (see

Loschiavo [2010] 130 fn. 52-54; 149 fn. 1 and 150 fn. 6 [to be placed in relation to KAISER (2004) 293 fn. 238]; 154 [the heading of c. 139; see KAISER (2004) 234]; 158 [the heading of c. 306; see KaISER (2004) 235]; 162 [the heading of c. 425 ; see KAISER (2004) 235] and 163 [the heading of c. 434; see KaISER (2004) 235]).

69 Loschiavo (2010) 121-128.

70 To see this, it suffices to observe the common peculiarities of the paratitla in the two manuscripts with respect to other testimonies (beyond the references mentioned to an alius codex in the Berlin manuscript), see Loschiavo (2010) 132-134; 149 fn. 2 and 4 , and 159 (especially the para- titlon to c. 332; regarding this point, see KaISER [2004] 300).

71 According to KaISer (2004) 304: »Wegen ihrer wörtlichen Übereinstimmungen besitzen die Par.B [and we can now include those of El Escorial] und die Par.WL einen gemeinsamen >Ursprung،. Ein gemeinsamer Archetyp dürfte angesichts der inhaltlichen Divergenzen unwahrscheinlich sein, zumal zusätzlich noch sprachliche Veränderungen anzunehmen wären. Die Par.B und Par.WL dürften eigenständige Werke darstellen. Die Gemeinsamkeiten zwischen Par.WL und Par.B wären dann mit einer Entstehung in demselben >Umfeld zu erklären. Hier liegt nahe, an einen Novellenunterricht (auf der Basis der Epitome Iuliani) zu denken.« Kaiser goes on recognising in these paratitla the product of one or more courses on the novellae constitutiones held in different years, perhaps by several professors or perhaps derived from notes taken in class by different students. 


\section{The Translations of the Authenticum}

Liebs imagined that the Authenticum was created at the school in Rome in the manner described above, i.e., by combining new and preexisting translations into something original. ${ }^{72}$ Furthermore, the appendix to the constitutions that August Biener claimed to recognise at the end of the Authenticum might have been integrated into the Latin collection. ${ }^{73}$ According to an ancient scholion contained in the El Escorial manuscript, this appendix is thought to only consist of Latin constitutions grouped together. If this is the case, then it is more probable that it was compiled in the West - most likely Rome - than in Constantinople (or anywhere else). ${ }^{\mathbf{7 4}}$

This hypothetical reconstruction of a Roman course focusing on the Novels seems even more probable if we look at the manuscripts once again. As Radding and Ciaralli already deciphered in reference to the Wien and Leipzig codes, »the common thread linking the manuscripts seems to be the city of Rome«. It was certainly in Rome, at the end of the $9^{\text {th }}$ century, that the Wien manuscript was copied, whereas the Leipzig code was drafted about two hundred years later in the Monte Cassino monastery - when Desiderius was the abbot (1057-1087) and the ties to the Curia were especially strong. ${ }^{75}$ It is also very likely that the two codes are both copies of a common ancestor preserved in Rome. Moreover, as we have seen and will soon become even more evident - the Berlin manuscript (which together with the Wien and Leipzig codes forms a fairly homogeneous group) ${ }^{\mathbf{7 6}}$ may also be linked to a Late Antique ancestor preserved in Rome.
Finally, we can stress another point. If, after the pragmatica sanctio, a school of law really was revived in Rome, it is reasonable to suppose that a certain space would have been reserved for the teaching of the most recent imperial legislation. Such legislation was, indeed, becoming abundant, and knowledge of this legislation was vital to those seeking employment opportunities afforded by the new Byzantine administration. Nor can we forget that, because of the topics considered, the new legislation certainly had to be of interest to the Papal Curia - perhaps more so than the other parts of Justinian's legislation. In fact, given that knowledge of the Greek language was on the decline, the study of the novellae constitutiones would have been much more difficult than that of the Code and Digest, we can thus reasonably assume that the demand for a course specifically dedicated to teaching the Novels was particularly great.

\section{At the time of Gregory the Great}

Even if we assume that the school in Rome was restarted after 554, it is, nevertheless, difficult to believe that - during such hard times - the same school was able to provide products and services of appreciable quality. We know that the imperial court preferred to fill the most important bureaucratic positions of the re-conquered Italy with officials sent from Constantinople. ${ }^{77}$ Moreover, it was very common for the wealthy to go study in Constantinople. Conversely, we might expect to find in Rome those students primarily aspiring to obtain only second tier bureaucratic positions. Assuming this was the case, we would not neces-
72 The origin of the Authenticum remains a mystery. Noting that the $A u$ thenticum might represent a collection of earlier translations of individual Novels gathered together, KAISER (2004) 366 has another argument against Liebs's thesis. The objection, however, is not decisive: Liebs's hypothesis, in fact, does not exclude the possibility that the $A u$ thenticum may not be a "Werkeinheit «, but derived from a "Zusammenstellung von Vorarbeiten«. More recently, Kaiser himself was more willing to accept Liebs's thesis: KaISER (2012), esp. 429.
73 This expansion of the collection most likely took place between 563 (the year of the publication of the last Novel present in that appendix) and 565 (the year when Nov. 138 was published), which, on the contrary, is not present (but which nevertheless arrived in the West).

74 See Loschiavo (2010) 135-136. Sceptical, however, KaISER (2012) 407 fn. 79 thinks the gloss alludes to the original Latin constitutions contained in the appendix. However, an alternative interpretation is possible: the final appendix might have consisted of translations into Latin of only some constitutions (i.e., wi- thout the original Greek text below the Latin - as it should have been in the original collection from which the Authenticum stems).

75 Radding / Ciaralli (2007) 41, 86. See also with reference to the Wien code only - Ciaralli (2002) 74-78. Point by point descriptions of the content of both codes can also be found in KAISER (2004) 146-160.

76 KAISER (2004) 67 and 165-166.

77 See, among others, FalkenHausen (1985), esp. 86-88, and Cracco RugGINI (1985), esp. 204-207. 
sarily expect either the teaching of high level courses or a great deal of originality in the Roman teaching. Within this framework, the rather modest testimonies previously mentioned concerning a possible course dealing with the Novels (i. e., mere repetitions of lessons already held elsewhere without appreciable new contributions) would match perfectly.

In any case, regardless of the level of the Roman education, it is even more difficult to imagine that the same school could possibly have remained active for very long after the death of Justinian. The idea of a renewal of cultural institutions in Rome - a notion still very much alive for the emperor in 554 - does not seem, in fact, to have generated any significant results. Cultural life (as well as the religious and political spheres) in Italy between the $6^{\text {th }}$ and $7^{\text {th }}$ centuries seems to be concentrated in the prominent, yet solitary figure of Gregory the Great.

While it is true that Gregory - if we just consider his legal education - shows a remarkable mastery of the entire Corpus iuris, it is quite unlikely that such knowledge stemmed from having attended the imperial law school in Rome (which should have been active during the time in which the future pontiff was studying). A young man of Gregory's social class could easily have had access to highly trained and knowledgeable private teachers. $^{\mathbf{7 8}}$ This would seem to explain why Gregory, despite the fact that he himself mentions several times that he read the Justinian Novels, does not know the Authenticum collection. ${ }^{79}$ In fact, we can easily suppose that, in this era, the use of the Latin collection was limited to the law school, and that the Latin kata poda had not yet been separated from the Greek texts. Nor can we be under any illusions about what Gregory himself writes in July 599 and, then again, in September 602 about scholars (docti) and learned persons (sapientes). ${ }^{\mathbf{8 0}}$
It would be easy to read into these statements an acknowledgement of his acquaintance with legal experts (perhaps persons allowed to give private lessons) or well-esteemed lawyers, but not - as Liebs, instead, believes - the testimony of the continuing vitality of an sinstitutionak law school. ${ }^{81}$ In any event, it is very likely that the school, after having been re-established by Justinian, suffered the same disastrous decline as the Senate: the institution to which, more than any other, the school was linked. Indeed, it is quite possible that the school ceased to exist even before the demise of the Senate. ${ }^{\mathbf{8 2}}$

10 The meaning of selecting and summarising in the $7^{\text {th }}$ century

Not everything, however, disappeared all at once; something must have remained. The complete set of Justinian books certainly remained. Gregory's references to scholars and learned persons make it at least conceivable that some form of teaching (perhaps at the primary level) involving legal texts could have taken place. ${ }^{83}$ The summae or summaria (summaries) of Epitome Iuliani and Codex offer possible evidence that some of the Justinian volumes continued to be the subject of exegetical readings (at the very least, individual readings).

As we have seen, Liebs connects both the summaria capitum to the Epitome Iuliani and those that were then assembled to form a continuous series in the Adnotationes codicum domini Iustiniani (alias Summa Perusina) back to the Roman law school. ${ }^{\mathbf{8 4}}$ Both series of summaries - composed, according to him, sometime between the end of the $6^{\text {th }}$ and the beginning of the $7^{\text {th }}$ centuries - also testify to the continued existence and persisting vitality of that school in the post-Justinian era. ${ }^{85}$ Although the
78 As rightly noted by Guillou (1972) 294, Gregorio's biographers do not provide us with much insight regarding the cultural education of the future Pope. See also Riché (1979) 17-18 and Richards (1980) 25-27.

79 In his famous letter addressed to $d e$ fensor John in 603, Gregory cites two Justinian Novels (among other Roman law texts): Nov. 90 (De testibus) and Nov. 123 (De episcopis et clericis). While the wording of the latter coin- cides with the Authenticum, for the Nov. 90, Gregory certainly used a different (and better) kata poda than that preserved in the Latin collection as showed by KAISER (2008) 606-613. We cannot exclude that Gregory had obtained those translations in Constantinople when he was sent there as apocrisarius by the Pope.

80 Ewald/Hartmann (edd.) (1809), Epistolae IX.197 (p. 186/11-13) and XIII.6 (p. 371/11-14).
81 Liebs (1987) 128-129.

82 According to STEIN (1939), the Senate ceased its activities in 593, when the Lombards of Agilulf became a serious threat to Rome.

83 In this sense, we have to consider the significant episode - mentioned by Liebs - concerning Gregory the Great (infra, fn. 138).

84 The text was studied and edited by Patetta (1900).

85 Liebs (1987) 269-273 and 276-282. 
Roman origin is generally accepted, ${ }^{\mathbf{8 6}}$ in this case, it is more difficult to accept Liebs's version of the story. There is no compelling evidence to suggest that those summaries had an educational purpose and were not, instead, the result of an individual effort. $^{87}$

If we then look at the summaria to the Epitome Iuliani (at least in the form in which we now know them) with the complex didactic method of the antecessores in mind - a method characterised, as we have seen, by a combination of indices and full texts (i. e., not summarised) of the Novels - the deficit is immediately clear. Half-a-century later, of course, the situation must have worsened. Whoever composed those summaries - as indicted by the scholars who studied the material - must have been poorly educated (also with regards to their legal knowledge). At any rate, even considering eventual errors resulting from the manuscript tradition, the summaria capitum testifies to the fact that someone in Rome was interested in reading the work of Iulianus, and that he was able to do so (even if the results were only mediocre).

Once more, it is useful to look at the manuscript tradition of these summaries (and again, Kaiser's work on the Epitome Iuliani proves helpful). First, it is much larger than expected. ${ }^{\mathbf{8 8}}$ In addition to the previously mentioned Wien and Leipzig manuscripts, these summaries are also found in a code of Vercelli (BC 122: here, however, there are fewer of them and sometimes with a different text). Moreover, we find them in a fascicle added to the same London code also containing the mysterious Collectio Gaudenziana (here also in the form of excerpta). Again, we are brought back to the Roman context: the code of Vercelli was surely copied in Rome during the $11^{\text {th }}$ century, ${ }^{89}$ while the supplementary fascicle included in the London Code, copied in the $12^{\text {th }}$ century in >Beneventan< script, has an ancestor clearly related to the ms. Wien 2160, which was also composed in Rome (or nearby). ${ }^{90}$ And here again - despite the two century gap separating the Wien code and later testimonies - the centre of sirradiation $<$ seems to be Rome.

Moreover, it is also well-known that the Summa Perusina stems from the region around Rome. Together with the summaries to the Epitome Iuliani, the Adnotationes - originally written in the margins of a Justinian Codex manuscript - have a number of features in common: the method (i.e., selecting and summarising the norms), the poor Latin (practically without any regard for grammatical rules), some typical linguistic expressions and peculiar terminology, the uncertain knowledge of Justinian law as well as some difficulties comprehending the legal text. There is enough evidence and material to support the idea of a common derivation of the two works from the same centre. ${ }^{91}$ Further supporting the Roman origin hypothesis is the fact that the Vercelli code contains not only the summaries to Julian, but also excerpts of the Summa Perusina.

Thus, it seems very probable that in Rome during the first decades of the $7^{\text {th }}$ century, someone was still capable of an exegetically reading of the Novels and the Codex. Even though such summaria sometimes seem to represent rough and quite inaccurate, they are, nevertheless, undeniable historical testimonies of a persistent interest in Justi-
86 Radding/Ciaralli (2007) 43. This is the case according to Patetta (1900) xlvii-viii. KaISER (2004) 346 is, however, slightly more sceptical. According to him, if the Italian origin is more probable, then »könnte eine eingehendere Untersuchung der handschriftlichen Überlieferung ... zumindest zeigen, daß Rom und dessen Einzugsgebiet die früheste greifbare Überlieferungsregion der Kapitelsummen darstellen«. Yet, if not in Rome, where should we locate the two works?

87 See Kaiser (2004) 326, 340 and 346 followed by RadDing / Ciaralli (2007) 38 and 41-44, who distanced themselves only from dating the original drafting of the two works for which they suggest »a date of around or even before the 600 «. See, however, D. Liebs (2006) 407-408 in his review of Kaiser's book and now in ID., The Scholia Veronensia on the Justinian Code and the Pistoia Codex Gloss: Roman Jurisprudence in Early Medieval Italy, in print, I, 3 (I am grateful to the author for letting me read the manuscript).

88 KAISER (2004) 320-335.

89 Descriptions of the code, in Ciaralli (2002) (with dating to the second half of the $11^{\text {th }}$ century) $85-90$ and KAISER (2004) 122-146 (first half of the $11^{\text {th }}$ century). Regarding the probable Roman origin, see RADDING / Ciaralli (2007) 41 fn. 13.

90 KAISER (2004) 320 and 665-666 (for a description of the London fascicle).

91 The correspondences did not escape Patetta's attention, Patetta (1900) xlvii. See also KaISER (2004) 341-346 and RadDing / Ciaralli (2007) 42-44. But while Kaiser (346), in line with the conclusions reached by $\mathrm{Pa}$ tetta, considers a dating to the mid$7^{\text {th }}$ century more likely, RADDING/ Ciaralli (2007) 69 think that the $6^{\text {th }}$ century is more probable, thus approaching what Liebs suggested. 
nian law. ${ }^{92}$ Such an interest in works like these cannot be attributed to mere cultural curiosity. As the often repeated mistakes seem to reveal, behind these efforts lay the attempt to adopt the Justinian texts - at that time often considered incomprehensible - into a new and different context: one now decidedly medieval. By means of these selecting and summarising activities, the memory (albeit corrupt) of the norms themselves was kept alive; however, this also means - and this warrants our attention - that the meaning of those texts was also preserved in the form of imperative rules. ${ }^{93}$

Framed in this way, we can perhaps better understand the difference that persisted between the summaries of the Epitome Iuliani and those of the Summa Perusina. While the latter appears to be uncoupled from the normative text already in the early $11^{\text {th }}$ century ${ }^{94}$ (having successfully instituted another widely used practise), ${ }^{95}$ the summaria to the Epitome remained linked to the main text. The Epitome Iuliani - unlike the Code - was, at that time, evidently not considered too challenging to be read in its entirety. To this extent, the summaria was also able to preserve the subsidiary function it originally had, that is, facilitating the consultation of the main text. We know, moreover, that the Epitome, originally written by Julian as a didactic tool, quickly prevailed in practical use, and meant that the integral texts of the Novels fell into oblivion. Over the course of these centuries, the Epitome embodied, almost par excellence, the lex iustiniana. ${ }^{96}$

\section{The sSilent Age}

The Epitome Iuliani is the most suitable text (relatively speaking) to assist us in penetrating or, at least, circumscribing - the dark shadow encompassing the period from the $\operatorname{mid}-7^{\text {th }}$ to the end of the $8^{\text {th }}$ centuries: a period representing the darkest and most silent age in the history of Justinian law in the Latin West. Of course, one can only hope to hear but a few faint voices: nothing more than simple signals. Such signals, however, should not be underestimated; they already herald that momentary (although significant) awakening, which would eventually characterise a much brighter $9^{\text {th }}$ century.

The strongest voices heralded from Gaul, where the Epitome Iuliani appears to have arrived much earlier. In fact, it is Ansegisus's use of the Epitome for his collection of capitularia that first attested to its presence beyond the Alps only starting in $827 .{ }^{97}$ The very equation to the Frankish capitularia something like a confirmation of their recognition
92 See especially CaLasso (1954)

288-289 and CoRTESE (1995)

240-242. A similar argument can also

be made concerning the drafting of those particular notes HäNEL (ed.)

(1873) II and L called salte Summen $\mathrm{o}$ >Lemmatar and that we find in the Epitome Iuliani of the ms. St. Gallen, Stiftbibl. 1395. According to ConRaT (1891) 125-127, they could be dated to Justinian times and might have been a translation of a number of headings in the Novels originally written in Greek. Observing that their author was not always able to correctly summarise the text, KAISER (2004) 219-223 thinks it more likely that they belong to the medieval West. An activity of this kind also generated the notabilia (or epitomae) in the margin of some constitutions of the Epitome Codicis Beinecke (New Haven, Yale Univ. Beinecke Library, ms. 974) recently studied by Dolezalek / Ciaralli (2010), esp.
93-94. The Epitome is written in romanesca script and could have originated in Rome during the second half of the $11^{\text {th }}$ century. Nevertheless, we can observe that whether, as appears to be the case, these notes were already present in the ancestor of the Yale manuscript, the possibility that they were redacted even prior to the $11^{\text {th }}$ century cannot be excluded.

93 Such a frame of reference assumes a different meaning for the exclusion of the chapters of the Epitome concerning the administration of the Eastern provinces from the summarising work (while they are still considered to be chapters concerning Constantinople or Eastern bishoprics); see LieBs (1987) 270 fn. 4 and KAISER (2004) 328. Regarding the peculiar binding value that the Roman law had for the medieval Church, it is useful to look at LEGENDRE (1964).

94 Both a description and dating of the code can be found in Ciaralli /
Longo, (2001) (partially different opinions about the Roman origin can be found on pp. 26 and 60-62).

95 Cortese (1995) 241; Chiodi (2002) 1145-1146.

96 The Epitome Iuliani is introduced in the ms. Paris, BN, lat. 4418 (France; saec. IX.1/4) precisely as Lex Iustiniana as well as in various other sources of the Carolingian era. It is also referred to as lex domni Iustiniani imp(eratoris) in the ms. Vercelli, BC, 122 and (even more interestingly) in its ancestor code: see KAISER (2004) 33 (fn. 47), 132 and 617 (fn. 9)

97 Ansegisus completed his collection of Capitularia precisely in that year; see GANSHOF (1969) 27-28 and KAISER (2004) 468-470. Alcuin (735-804), on the contrary, does not seem to know the Epitome Iuliani; see Conrat (1891) 25 . 
within the realm $\mathbf{9 8}^{\mathbf{8}}$ - seems to strengthen the argument that the Epitome had already arrived in Gaul sometime during the $8^{\text {th }}$ century. And if we lend credence to the chronicle of Mossiac, it is even possible to provide a reasonably accurate date of arrival. The author tells of how, in August of 739, Pope Gregory III sent letters, relics and other gifts to Charles Martel, at that time, subregulus of the Franks.

Among the gifts, there were »decreta romanorum principum «. ${ }^{99}$ The episode did not go unnoticed in the historiography. ${ }^{\mathbf{1 0 0}}$ It occurred to some scholar that, perhaps, a copy of the Codex Iustinianus ${ }^{101}$ was sent, especially when we consider its use (typical of canonical and monastic environments related to the teaching of the artes and substantiated in France until the $12^{\text {th }}$ century), in order to refer to the imperial constitutions using the very same term decreta. ${ }^{\mathbf{1 0 2}}$ The same term, however, is occasionally used with reference to the Epitome Iuliani. ${ }^{103}$ Given that the original Justinian Code was no longer used in Italy at that time, it is conceivable that the Pope sent, instead, a copy of Julian's work to Charles Martel. Whether or not this is accurate, the chronicle of Mossiac remains an expression of a trend that would emerge with increasing clarity with each passing decade.

There are, nonetheless, other reasons to suppose that the Epitome Iuliani had been circulating throughout Gaul prior to the end of the $8^{\text {th }}$ century. Having studied the Summa novellarum De ordine ecclesiastico, Conrat seems convinced of this point. Both he and Kaiser, despite the great span of time, believe that this selection of chapters from the Julian collection, grouped by topic and highly summarised, could very well be a Gaulian product. ${ }^{104}$ While a French origin of the short text is entirely possible, one can hardly exclude its derivation from Italy. This means that we have to consider the very telling manner in which chapters are defined (i.e., innovationes legum novellarum divae memoriae Iustiniani), as well as the similarities (in regarding form and method) to the previously discussed Summaria capitum. ${ }^{105}$

Irrespective of whether the text was penned in Gaul or Italy, the most intriguing thing about it concerns the possible origin of the materials used by its author. In this regard, another aspect of the
98 The Epitome Iuliani was then utilised by Benedict Levita (but throughout the Summa de ordine ecclesiastico - see infra), by Hincmar of Reims and in various councils; see CoNRAT (1891) 39.

99 Cronicon Moissiacense (ed. Pertz, MGH SS, I, 1826), 291-292.

100 See, for example, Classen (1983) 100 and Cortese (1995) 177.

101 This is according to ConRAT (1891) 36-37; and then Liebs (2002) 101 as well.

102 Conrat (1891) 37 fn. e. Regarding the persistence of that meaning until in the $12^{\text {th }}$ century in France, several examples can be found in Gouron (1993) s. IX, p. 14 and L. Loschiavo (1996) 50. On the one hand, Beda utilises the expression decreta ... iudiciorum to define the Code of Æthelberth: see Colgrave/Minors (1969) II.5, p. 150, 1l. 12-14.

103 Perhaps from Pope Eugenius II in July 824 (assuming the letter addressed to the bishop of Vienna is authentic, in which the Pope, wishing to answer a juridical question (causa) posed to him, writes that (Epistolae Viennenses spuriae, ep. 20, ed. Gundlach, MGH Epp., III [Mero- wingici et Karolini aevi, I], 1892, 98-99): »... quantum potuimus, recursu lectionis illam in scriniis nostris investigavimus, et quicquid post auctoritatem Romanam in Iustiniana || etiam lege comperimus, tuae sanctitati per nostros apices intimamus. In capitulo DXI (const. 119 c. 501) eiusdem legis ita invenimus, ut praescriptio quadraginta annorum venerabilibus locis ... «; see Conrat (1891) 15 . The expression is surely used in that sense in the polemic pamphlet written in 1085 (within a Gregorian context) entitled Liber canonum contra Henricum IV (ed. Thaner, MGH, Libelli de lite Imperatorum et Pontificum, I, 1891, 486) c. 12: »... Iustinianus imperator in decretorum suorum constitutione CXVIII, capitulo CCCCXLI (Ep. Iul., C. 115 c. 441)«; see LEgENDre (1964) 55.

104 See Conrat (1898) 22 and now KAISER (2004) 470-492 (esp. 474-475). Arguments in favour of a French origin can be summarised as follows: a) the diffusion besides the Alps of the Summa (used by Benedict Levita) and the Burgundian origin of the manuscript from which we know the text (ms. Berlin, SB. Phill. 1735; saec. VIII ex. / IX in.); b) the use of a couple of juridical terms in the text (causare for "to act in trial « and precaria) which are characteristic of the Burgundian region; c) its similarity to the ms. Berlin, SB lat. fol. 269, which was, according to Kaiser, also compiled in Burgundia (see infra, fn. 108 and 109). None of these are actually decisive: they surely demonstrate the diffusion of the text within the French regions, yet they cannot exclude the possibility that it was an imported product. For instance, Siems (1992) 187 contends that it was of Italian origin.

105 As in the summaria, in fact, we find here the names of the ancient (and, at that time, missing) Roman magistrates preserved, and all chapters concerning Eastern churches were removed. We also notice some misunderstanding of the normative text, such as in the use of late-Latin terms like componere (for paying a fine): see KAISER (2004) 473-474 and 865. BESTA (1923) 262 also thinks that it is of Italian (from Romagna) origin; however, he does not provide any substantial evidence to support this contention. 
Summa De ordine ecclesiastico warrants our attention: the selected chapters show undeniable textual similarities to the Epitome Iuliani of the ms. Berlin SB, lat. fol. 269. According to Kaiser's reconstruction, the author of the Summa had access to a text from the Epitome quite close to the second recension of Julian's work as found in the Berlin code. ${ }^{\mathbf{1 0 6}}$ It is possible - indeed quite likely - that a manuscript very close to the Berlin one (either the antigraph or one of the antigraphs) was the vehicle through which the Epitome arrived in Gaul prior to the end of the $8^{\text {th }}$ century. ${ }^{107}$

Up till now, the ms. Berlin lat. fol. 269 has been mentioned several times and in various contexts. The time has come, however, for us to consider the Berlin code itself and have a closer look at the complexity of this work.

\section{A very interesting Berlin manuscript} (and its relatives)

The ms. lat. fol. 269 in the national library in Berlin is one of the most well-known and discussed codes among scholars of medieval legal history. While its dating back to the early part of the $9^{\text {th }}$ century (or perhaps even to the end of the $8^{\text {th }}$ ) is generally accepted, the question concerning its place of origin is far more controversial. ${ }^{\mathbf{1 0 8}}$
Since the time of Mommsen, scholars have been captivated by the presence of a fascicle containing the last part of the Institutes and the early titles of the Digest. ${ }^{109}$ The close relationship between these Institutes to those in Bamberg has already been mentioned. The very precocious testimony that the fascicle offers with regard to the Digest was naturally far more interesting to the scholars. With sound arguments, it has been suggested that the antigraph from which these initial passages were copied was Byzantine in origin and dates back to the $6^{\text {th }}$ century. ${ }^{110}$ Another interesting question concerns the (rather unusual) sequence of Institutes / Digest: was the arrangement random or did it follow a certain pattern? Since the second answer seems easier to accept, we need to enquire into its specific origin. Among the various explanations put forward, Francesca Macino's suggestion is worth noting: the antigraph that is behind the Berlin fascicle may have been a code prepared in the Justinian era ad usum scholarum, i. e., compiled in compliance with the school programmes set forth by Justinian himself. As we know, these programmes prescribed that the Institutes, together with the first four books of the Digest (const. Omnem $\$ 2$ ), be treated during the first year of study. ${ }^{111}$

We are again brought back to the Age of Justinian. Compiled perhaps in the East, ${ }^{\mathbf{1 1 2}}$ what-
106 See KAISER (2004) 59-67 (about the two recensions in the code), 466-468 and 473 (about the similarities of the Summa to the second part of the Berlin ms.).

107 This is what KaIser (2004) 101, 171, 396, 637 and 849 seems to suggest.

108 KAISER (2004) 39-102 provides a meticulous description of the code. Generally speaking, scholars tend to agree about the dating of the code, but not about its possible place of origin. Many of them accept B. Bischoff's opinion (BIscHOFF [1998] 76 nr. 365) without paying much regard to its dubitative form (vielleicht) and think of South-Eastern France (Burgundia): see RöHLE (1968), esp. 132-133); Fingernagel (1999) 56-57 nr. 52; KAISER (2004) 86-102, and Radding / Ciaralli (2007) 49-50. Mor (1977) 114-115, indeed, favours the North of Italy. Initially NicolaJ (2001) 487 and, more recently, BELLONI (2008) 8-9 thought it to be of Roman origin. Later, the same Nicolaj (2005) 779-780 indicated rather the North of Italy; more precisely, the Nonantola territory. In the same sense, Macino (2008) 26-28.

109 See above, p. 88-90 [fn. 45-50]. The fascicle - carefully studied by Kaiser could derive from a code copied during the same period (the Carolingian age) and perhaps even in the same environment (the Monastery of Flavigny). According to Kaiser, both the fascicle and the remaining part of the Berlin code might not just be the same age, but also share a common origin, i. e., the same scriptorium in Burgundia (KAISER [2004] 39-102 and 387-415, especially 393-397). Patetta (1967b) 150-158 and Macino (see the previous footnote) also think that the fascicle appears to have been created at the same time as the rest of the code and originated in the same environment (but not in the
Burgundia). Regarding the notable level of the juridical culture in Burgundia during that era as well as concerning possible testimonies in this sense, please see EsDERs (1997) 473-503 and LiEBs (2002) 230, 253 and 254-258.

110 After Conrat (1891) 72; Patetta (1967b) 153 and RöHLE (1968) 139-142, see KAISER (2004) 400-405 and 414.

111 Macino (2008) 25-26. Concerning the law school curriculum under Justinian, see Liebs (2008), esp. 37-39.

112 KAISER (2004) 414 has in mind a "Pergamenthandschrift in BR-Unziale ... die im Osten noch in sechsten Jahrhundert entstand «. We should remember that Patetta already placed its origin in the Byzantine Italy (supra, p. 89). 
ever its form was, the Late Antique model soon arrived in Italy and here (in a school environment that could easily be the Roman one) it was used for copying (at least for the part which contained the Institutes). ${ }^{113}$ Not in the East, however, but in a western region, the antigraph of (that part of) the Digest was later glossed as evidenced by a couple of very brief notes that a $9^{\text {th }}$ century scribe slipped into the main text by mistake. ${ }^{\mathbf{1 1 4}}$ The extreme brevity of the notes does not permit a more precise determination of their age (yet, they are certainly older than the Berlin apograph) and origin (but we have to remember that one of the two notes previously discussed exhibits a certain similarity to a parallel gloss of the Bamberg manuscript). ${ }^{\mathbf{1 1 5}}$ In any case, even if it is difficult to believe that the glosses stem from the Justinian Age, they, nevertheless, originate from a context associated with the reading of the Digest (or, at least, the first part). ${ }^{116}$

Beyond the mysterious fascicle, the Berlin code contains the Epitome Iuliani - one of its most interesting testimonies - and the Collatio legum Mosaicarum et Romanarum (Lex Dei) - which is certainly the oldest example among the three known to us. Considering the textual tradition of the Epitome Iuliani, the code reflects - as mentioned before - two different recensions. The first part of the text (corresponding to chapters 1-117) falls within the so-called >Textgruppe $\mathrm{D}<$, which also includes the codes of Wien (lat. 2160), Leipzig (Hänel, 6) and Vercelli (BC 122). ${ }^{\mathbf{1 1 7}}$ In the preceding pages, all of these codes have been touched upon due to the presence of paratitla and summaria capitum. However, it is, above all, the presence of an integrated version of the so-called appendix $B$ to the same Epitome that transforms them into a closely related group. The integration consists of a small set of texts originating in Constantinople, among them the Dictatum de consiliariis and the Collectio Iuliani antecessoris (or de tutoribus). ${ }^{\mathbf{1 1 8}} \mathrm{We}$ are, again, dealing with texts that originate from the legal teaching of Late Antiquity.

The Collatio legum Mosaicarum et Romanarum also belongs to the Late Antiquity, and the Berlin, Wien and Vercelli codes (three of the four members of >Textgruppe $\mathrm{D}<$ ) are the sole remaining testimonies. ${ }^{119}$ Almost every aspect of this unique comparison between the Roman and Mosaic laws is engulfed by uncertainty. Pretty much the only thing we can say about this text with any degree of confidence was that it was particularly suited to the tastes of ecclesiastical circles. ${ }^{\mathbf{1 2 0}}$ And it is in one of these circles - in the atelier of the Archbishop of Reims, Hincmar - that, in 860 , we find the first solid evidence of its existence ${ }^{\mathbf{1 2 1}}$ (especially when the idea that the Lex Dei had already been circulating in Gaul during the first half of the $6^{\text {th }}$ century nowadays seems dismissible). ${ }^{\mathbf{1 2 2}}$ However, of particular interest to us here is the fact that Hincmar's copy was, indeed, very close to that of the Berlin code, ${ }^{\mathbf{1 2 3}}$ and that he was also among the few who owned a copy of the Epitome Iuliani.

Kaiser might have been right in thinking that the Epitome Iuliani and Lex Dei arrived in Gaul already bound together (for the Collatio could not
113 As has already been mentioned ( $s u$ pra, p. 90), we should imagine a centre containing multiple exemplars of the Institutiones and where it was also possible to draft copies. It is entirely possible that one of those exemplars had the form Macino imagined (see above, fn. 111), and, furthermore, that one of the copies was the source of the Berlin fascicle.

114 Mor (1977) 119 noted them first, but here it is worth looking at Kaiser's point by point analysis, KAISER (2004) 412-414.

115 Supra, p. 89 fn. 45.

116 What RadDing / Ciaralli (2007) 50 affirm, namely that »the fascicle, in any case, contains no glosses. ... this book evidently found few readers and had no discernible impact on the culture of this time«, is relevant for the copy (the Berlin code), but not for its ancestor.

117 KaISER (2004) 122-171.

118 KaISER (2004) 16-19, 354-360, $361-366,381$.

119 There is a great deal of literature on this subject. We need only recall the recent and comprehensive work by Frakes (2011). Concerning a probable dating, Frakes (35-65 and esp. 59-65) suggests the last decade of the $4^{\text {th }}$ century and, more precisely, the 'window< between 392 and 395 .

120 Loschiavo (2006), esp. 99-102) and now Frakes (2011) 35-48.

121 De divortio Lotharii regis et Theutebergae reginae, Interrog. XII, resp. (ed. Böhringer, MGH Conc., IV Suppl. 1, 1992, 177/42-44 and 185/2-4).

122 Contrary to MiкAт (1994) 55-58, 125-126 and 130-131, who thought that the Collatio could have been consulted during the Councils of Orléans (538), Tour (567) and Mâcon (585), see now Manthe (2011), esp. 396-3988) (I am very grateful to D. Liebs for referring me to Manthe's work). According to an old hypothesis formulated by BeYERLE (1926) lvi-lxi, the Collatio could have, instead, be used by the compilers of the Lex Baiuvariorum (A. 740 ca.); see also LANDAU (2004).

123 Frakes (2011) 44 
have been the sole arrival). ${ }^{\mathbf{1 2 4}}$ The sequence Epitome Iuliani-Lex Dei was, indeed, already present in the manuscript (or in one of the manuscripts) from which the Berlin code originated. ${ }^{125}$ It is interesting to pursue the issues concerning the origin of this specimen and when it might have crossed the Alps. Considering the dating of the Berlin code (between the end of the $8^{\text {th }}$ and beginning of the $9^{\text {th }}$ centuries), its ancestor (the antigraph or the antigraph of the antigraph) could easily date back to the last decades of the $7^{\text {th }}$ century. To identify the possible place of origin, we are able to draw conclusions from the numerous observations already made to the Berlin code in this contribution.

We can begin by acknowledging how the antigraph of the Berlin manuscript must have been prepared in a centre where, at that time, copies of the Institutes and the Digest (or, at least, its first part) were still available. While these specimens descended from archetypes dating back to Late Antiquity, they, nonetheless, bare traces of early medieval readers (i. e., the two notes slipped into the fragment of the Digest). We can also conclude that the Novels, in the summarised form in which they appear in the Epitome Iuliani, were also kept at this centre. Together with the Epitome Iuliani, though, they have probably retained traces of Late Antique teachings of the Novels according to the method of Justinian's antecessores (we need only to remember the paratitla to the Epitome and the references to an alius codex with the full text of the "new « constitutions). Moreover, specimens of other writings coming from the school of Constantinople as well as other full or summarised texts of the Novels (the so-called appendix $B$ to the Epitome Iuliani) were preserved (and considered worthy of reproduction and circulation). These Byzantine relics were not only the reflection of a reverential attitude toward the past. As we will see, these other texts (in particular the Dictatum de consiliariis) must have been read, understood and worked with.

Finally, we have the Lex Dei; a work that had nothing to do with Justinian, but which the ecclesiastical hierarchy, nevertheless, held in high esteem, and that only the Church could have had an interest in both preserving and disseminating.

\section{Was there a centre of legal culture?}

As we have seen in the preceding pages, we have access to a very rich repository of Roman legal texts. When it was deemed necessary or requests were made, copies of these ancient manuscripts were provided. If this had not been the case, then we would not have the apographs from the $9^{\text {th }}$, $10^{\text {th }}$ and $11^{\text {th }}$ centuries (which testify to their existence). ${ }^{126}$ It is even plausible that, on those occasions when such reproductions were made, there was someone who was able to collate between the manuscripts (e.g., the contamination of texts is both revealed by the oldest manuscripts of the Institutes ${ }^{\mathbf{1 2 7}}$ and clearly reflected in the composite text of the Epitome Iuliani in the Berlin manuscript). ${ }^{128}$

The very activity of copying and collating texts, however, seems to indicate that we are dealing with something more than the mere sstorage of books . We might even suspect the presence of a centre of legal culture (of course, in the sense that such an expression would have been meant in the West between the $7^{\text {th }}$ and $8^{\text {th }}$ centuries). The suspicion becomes more substantial - and the possibility more likely - when we consider how some of these texts were sometimes subjected to readings and other such activities. We have seen how the chap-
124 The ms. Paris, BN, lat. 9652 (Codex Bellovacensis) contains a quote from the Lex Dei and was surely produced in France (saec. IX/X). It indicates a textual tradition different from that to which the Berlin, Wien and Vercelli manuscripts belong; see Frakes (2011) 47-48. The parish code might also descend from an ancestor that arrived separately in Gaul (see supra at fn. 122).

125 See KAISER (2004) 101, 171 and 396, and, then, see Frakes (2011) 39.
126 Also infra, p. 102.

127 See supra, p. 90.

128 KaISER (2004) 59-67.

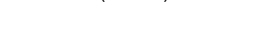


ters of the Epitome Iuliani have been subjected to a careful process of selection and summarisation (e. g., the summaria capitum as well as the first draft of the Summa De ordine ecclesiastico). When not present or available, some texts were given new headings in order to facilitate their consultation. ${ }^{129}$

A centre of this kind must have been unique in early medieval Europe. If we ask where such a centre might have been located, the most obvious and plausible candidate is Rome. A major push in this direction comes, first and foremost, from the study of the manuscript tradition. The oldest complete testimony for the Justinian Institutes (Bamberg ms.) comes directly from Rome. Furthermore, three of the four codes from sTextgruppe $\mathrm{D}$ of the Epitome Iuliani (mss. Wien, Leipzig and Vercelli) are of Roman origin.

Both the Adnotationes codicum (alias Summa Perusina) - very close to the summaria to the Epitome Iuliani - and the marginal summae to the Code - certainly similar, in more than one respect, to that of Perugia - also lead us to Rome (or the region of Rome: the Epitome Beinecke is also written in romanesca script and is dated to the second half of the $11^{\text {th }}$ century). ${ }^{\mathbf{1 3 0}}$ From these exegetical notes, we can also presume the presence of the Justinian Codex in Rome. Given the completeness of the texts, the accuracy in transcribing the $s u b$ scriptiones and the Greek numbering of titles and constitutions, it also becomes reasonable to postulate the presence of a specimen of the Codex in Rome when examining the fragments of the Codex now kept in Würzburg (UB, Mpjfm 2: sec. XI/2). In this case, we are also confronted with a text in romanesca script that, moreover, betrays similarities to the Bamberg Institutes and, in particular, to one of the scribes who copied the two volumes of the Moralia in Job located in the Vatican Archive (where the work was surely produced). ${ }^{\mathbf{1 3 1}}$ It is not difficult to imagine the existence of an ancestor of the Code from Late Antiquity (including the last three books), that would have completed the series of Justinian books present in Rome. ${ }^{\mathbf{1 3 2}}$

At this point, the presence of the Lex Dei in the Berlin, Wien and Vercelli codes deserves special attention. It is quite certain that this little work first saw the light of day in Rome around the turn of the $4^{\text {th }}$ century. ${ }^{133}$ Another of the early medieval ssafe citations of the Collatio, i. e., contained in the Collectio canonum in V libris, is also linked to Rome (or at least to central or southern Italy). ${ }^{\mathbf{1 3 4}}$ It is certainly significant that the antigraph, from which the author of the canonical collection drew in the early decades of the $11^{\text {th }}$ century, shows definite similarities to the three codes of >Textgruppe D . Such similarities relate to both the text of the Epitome Iuliani and the joint presence of the Epitome and Lex Dei. ${ }^{\mathbf{1 3 5}}$ In conclusion, it is reasonable to assume the derivation from a common ancestor.

The Berlin code $(B)$ is apparently the only one of the four testimonies to the Lex Dei that does not lead back to Rome. Among the four, however, it is also the oldest work (VIII/IX sec.). The variations existing between the Berlin code and the other three testimonies (and which concern both the text of Julian and the Collatio) indicate that an intermediate exemplar did exist within the tradition. From this work $(\alpha)$, both $B$ (or perhaps better $\alpha$,
129 The chapter headings of the Lex Dei show evidence of such additions, which are certainly early medieval products; see Conrat (1891) 313 and KAISER (2004) 170 and fn. 786. The headings of the individual chapters might also have been the work of a Westerner (conscious, however, of both the juridical terminology used under Justinian administration and the ecclesiastical organisation) as LiEBS (1987) 231-232 thought and also KAISER (2004) 216 and 218 considered plausible.

130 Dolezalek / Ciaralli, Codicis Justiniani (2010) 93-94.

131 Regarding the Würzburg fragments after the announcement was made by
WeIgAND (1988) 784-785, see especially Ciaralli (2002) 90-92.

132 According to Nicolaj (1991) 75-78, the path returning to the use of the Justinian Codex in the $11^{\text {th }}$ century started from the Latium, moved along Tuscany to arrive in North-Italy and then to the regions beyond the Alps. This thesis is now taken up by Macino (2008) 52, who has extended it to the Institutes, and by A. BelletTINI (2009), here 47 fn. 119, however, regarding the Codex - including the last three books. According to LieBs (Scholia Veronensia, I.3 toward the very end), the Verona palimpsest manuscript with the Justinian Code and the Greek Scholia as well (a ms. that originated in the East during the $6^{\text {th }}$ century) »had come to Verona from Rome $«$.

133 See Liebs (1987) 162-174, esp. 165-166. Frakes (2011) 129 is more cautious and suggests that the author of the Collatio: "... wrote in at least the western half of the Roman Empire. ... it is likely that he might have at some point been in Italy and it is tempting to contemplate that he could have studied law at Rome".

134 See here Reynolds (1990) 286, who considers a triangular origin, i. e., Rome - Chieti - Montecassino, to be probable.

135 KAISER (2004) 636-637. 
antigraph of $B)$ and the common ancestor of the mss. Wien ( $W-$ sec. IX.2) and Vercelli $(V-$ sec. XI), i. e., $\beta$ (sec. VIII/IX) as well as the antigraph of the Collectio in V libris, i.e., $\gamma$ (sec. XI.1) would have originated. ${ }^{136}$

At this point, it is easy to locate $\alpha$ in Rome and think that $\alpha$, apograph of $\alpha$ and antigraph of $B$, could actually be the vehicle Kaiser had in mind and by means of which, during the second half of the $8^{\text {th }}$ century, the Epitome Iuliani and Lex Dei crossed the Alps (as one edition bound together). ${ }^{137}$

14 Rome between Byzantium and the Frankish realms: the Pope, politics and the law

We probably have not sufficiently examined the reasons that led someone, in the mid- ${ }^{\text {th }}$ century, to make new copies of a Late Antique text such as the Collatio, nor why someone began circulating it as a bound edition together with the Epitome Iuliani - almost as if to intentionally create this specific scoupler. What the textual tradition allows us to imagine, in fact, finds support when taking a few other points into consideration: our attention has shifted from the plane of a mere presence and knowledge of Roman legal sources to the dimension of political history and the history of ideas.

First of all, it is not difficult to imagine that precisely in the See of Peter, in its ecclesiastical libraries and in the episcopium Lateranense (later palatium Lateranense), that a work such as the Collatio legum Mosaicarum et Romanarum could have survived for such a long time, even after Justinian had imposed the validity of its legislation within Italy as well. ${ }^{\mathbf{1 3 8}} \mathrm{We}$ can observe that, on the one hand, the possibility of sending the combination of the Epitome Iuliani - Lex Dei across the Alps fit perfectly within the broader movement, where Rome, between the $6^{\text {th }}$ and $8^{\text {th }}$ centuries, played "an essential role in the distribution of ancient manuscripts throughout the whole of the European West «. ${ }^{139}$ On the other hand, such efforts might find their specific location and motivation in the unfolding of quite peculiar and well-known historical circumstances.

These special circumstances were enacted when the Isaurian dynasty ascended the throne of Constantinople. From that moment onward, the reasons for the papacy's discontent and apprehension grew. In addition to the constant threat by the Lombards, they now (from 726) had to add the intrusive and pernicious religious policy the new Byzantine rulers were determined to implement. By the middle of the $8^{\text {th }}$ century, this apprehension turned into real impatience with the crown in Constantinople. Faced with this situation, the pope was forced to search for a strong ally, and thought he had found it in the Merovingian kingdom.

In those few short decades spanning the pontificate of Gregory II (715-731) to that of Stephen II (752-757), the leading role played by the Roman pontiffs radically changed the policy situation throughout the European continent. Rome - a city centred around its bishop - now consciously assumed a whole new role. Once again, Rome was a centre of political power. ${ }^{140} \mathrm{~A}$ project was drawn up, which, although quite bold, went on to enjoy a bright future. This well-known project consisted in creating a »new order « to be imposed on »Roman « Christendom: a decided shift of the barycentre from the Mediterranean East to the Continental West. Conscious adoption by and active collaboration with the new reges transalpini in implementing this new project were fundamental requirements. First of all, it was necessary »to convert« the Frankish sovereigns, transmit to them the ideals as well as the institutional and legal cornerstones
136 What I am proposing is, in practise, an integration of the stemma codicum, drawn up by SchuLz (1946) 314-315, and can be seen as related to what FRAKES (2011) 51 has suggested.

137 Supra, fn. 107.

138 Conrat (1891) 130 did not doubt that the Lateran library kept some "treasures" of this kind until the $11^{\text {th }}$ century. An important piece of evidence that Roman libraries preserved ancient legal texts - even pre-
Justinian, such as the Collatio and even from the emperors who were "enemies of Christians « - is provided by Gregory the Great. Writing in 593 to his friend Theodore, personal physician to Emperor Maurice, to ask him to persuade his imperial assistant to mitigate the wording of an unwelcome provision, Gregory recalls an earlier law drafted by Julian the Apostate, the contents of which he had been informed by those »qui le- ges noverunt (Registrum Epistolarum [fn. 80], Ep. 3.64 p. 225/22-23); see Liebs (1987) 127.

139 According to Petrucci (1972) 318. In the same sense, also see SupINo Martini (1987) 22-23 and 28 and Ciaralli (2002) 96.

140 Bertolini (1941) 197-200 and 535540 and now, especially, CORTESE (1995) 173-207 and CoRTESe (2001). 
upon which the new policy could be built. The planned secession from Byzantium, in fact, would not have meant an abandonment of the romanitas. ${ }^{141}$

Law, as commonly known, follows policy. It is realistic to think, under such circumstances, that someone within the Curia had the idea to create a new >law book by intentionally binding together the Epitome Iuliani, Lex Dei and that short series of texts that forms the appendix $B$ to the Epitome.

There are several good reasons to believe that the sodd coupler produced - i.e., Epitome Iuliani and Lex Dei - could have proven useful to achieving its intended purpose. Just considering the structure of this Late Antique work, makes evident the suitability of the Collatio toward realising a new alliance between papacy and monarchy - an alliance that, furthermore, had to be in agreement with God's will. Moreover, the Collatio had the great advantage of being quite suitable to the already widespread and internalised normative background of the cultural elites all over the continent. The scheme, where the cogency practise of the Decalogue and the divine and natural foundation of the law are clearly laid out, was introduced at an early age by reading the Etymologiae of Isidore in school. It finds its immediate manifestation in the Lex Dei. Here, Roman law is presented as the natural integration of divine law, as the unfolding of the latter according to a more complete and comprehensive description of the behaviours contrary to religion and the corresponding sanctions. ${ }^{142}$

On the other hand, the role played by the Epitome Iuliani was, to an extent, different and perhaps even more complex. It is completely understandable that the Roman Church was tied to the ancient school book. There is no doubt, in fact, that Julian's summary - finally free from the prolix and less comprehensible texts of the Novels (in their integral version) - represented the perfect response to its real world needs. In particular, the Epitome Iuliani not only reaffirmed the primacy of the Roman See before the entire Christian world, but also regulated many important aspects of the life of the religious institutions (privileges and discipline of the clergy, church property, marriage, inheritance, organisation of hospitals and orphanages, preparation of documents, rules of evidence in court, etc.). These rules, in light of their »social « relevance, however, needed to be accepted and implemented by the secular power. In this respect, such a short book also had the great advantage of being easily integrated into the existing system without introducing further complications to the already complex texts belonging to the Theodosian tradition and which were already widespread beyond the Alps.

Indeed, the idea that such texts collected in the Breviarium and already widely circulated in the summarised forms (epitomae) would suddenly be abandoned seems extremely implausible. With this tradition in mind, the Epitome Iuliani might have been intended as a further new >update of the early medieval Lex romana. This is precisely what is suggested by the comparison with the composition of the ms. Paris, BN, lat. 4418, drawn up in the early $9^{\text {th }}$ century (i.e., at the same time or shortly after the Berlin manuscript) and, most likely, within the court of Louis the Pious. In it, the Breviarium (in the summarised version called Epitome Aegidii) is divided into several sections, each named after a different legislator (Theodosii liber I ... Novellae divi Martianii liber I ... Gai liber I ...). The Epitome Iuliani follows immediately under the title of Lex Iustiniana; just as one would expect if it were intended as an upgrade to a continuous series of norms. ${ }^{143}$
141 According to Schramm (1992), see CoRTESE (1995) 202-204 and LEgENDRE (1964) 22-24.

142 Loschiavo (2006) 95-102.

143 KaISER (2004) 30-31. Codes in which the Epitome Iuliani appeared attached to the Breviarium Alaricianum, which circulated not only in France, but (probably) also in Italy during the Carolingian period; see Patetta (1967c) 637-641. If we needed further evidence for such a meeting of different traditions, we need only remember the presence of an extract of the Epitome Aegidii in the ms. of Vercelli (BC, 122; f. 159vb) or the already mentioned and expressive incipit of the Summa De ordine ecclesiastico: "Incipiunt innovationes legum ...«. 


\section{Conclusions}

There is, therefore, reason to believe that the link between the Epitome Iuliani and Lex Dei was not in the least fortuitous: behind the unification of the two texts, one clearly recognises the intention to give concrete expression to a »new « Roman and Christian law. In other words, those kings preparing to become the new masters of Western Christianity ought to make this new law their own law (or, at least, this was what the Roman clergy were probably thinking at the time). Mere distribution of those rules would, however, not suffice. With this in mind, the popes undertook efforts to persuade the reges Francorum, as testified to by the famous cases of Gregory III and Charles Martel in 739, Stephen II and Pepin in 754, Paul I and the same Pepin in the years 757 and 758 . It is easy to imagine that during those meetings and exchanges of solemn promises and magnificent gifts that the popes also gave the sovereigns a »new« legal text from the Roman tradition together with the explanation of its value (just as is suggested by the chronic of Mossiac mentioned earlier).

There is one episode, in particular, that is worth briefly mentioning here. First, it helps in understanding how the interest of the papacy, as well as ideal and abstract connotations, could occasionally attain a genuine legal concreteness. Second, it also represents an opportunity to find further confirmation of some of the many conjectures made in this contribution. It is the story of the contrasted privilege of the centennial prescription in favour of the Church of Rome. ${ }^{144}$
In 535, with the Nov. 9, Justinian had reiterated, only with reference to the Church of Rome, the privilege of centennial prescription already introduced by a precedent imperial norm to the benefit of churches and town communities (C. 1.2.23). In two successive Novels dated 541 and 545 (Novv. 111 and 131.6), the same emperor, however, had withdrawn the concession and reduced the privilege for all the churches (including, therefore, that of Rome) to (only) forty years. These events are, according to the interpretation of the antecessor Julianus, recorded in his Epitome Novellarum and Dictatum de consiliariis.

This privilege, however, had to be particularly dear to the popes; thus, they did not simply let the issue go uncommented. John VIII mentions it in 873, when he asked Louis the German to respect it in the context of the ancient Roman rules (venerandae romanae leges). ${ }^{\mathbf{1 4 5}}$ John VIII, however, was not the first to rely on the application of the privilege. It is certainly not surprising that it was invoked by Gregory the Great, who, nonetheless, does not make any specific reference to the norms. ${ }^{146}$ On the contrary, it is far more striking to see Pope Adrian I recalling the centennial prescription when, at the beginning of 775 , he implores Charles (who had just become patricius Romanorum) to respect this privilege. ${ }^{147}$ We must consider that for those who could only rely on the Epitome Iuliani, it was difficult to escape the strict wording of the relevant chapters (chapters 44, 366 and 511). ${ }^{148}$ In fact, the idea had already been circulating that, despite the wording of the chapter 44 of the Epitome (praesens constitutio ... innovata est
144 The story is well-known; above all, see the recent contributions of KAISER (1999) and Loschiavo (2007).

145 »Nemo de annorum numerum resultandi sumat fomentum, quia sanctę Romanę ... ecclesię privilegia ... nullis temporibus angustantur, nullis regnorum particionum preiudicantur. Set et venerande Romane leges divinitus per ora piorum principum promulgate rerum eius prescriptionem nonnisi post centum annos admittunt « (ed. MGH Epp., VII, Epist. Karol. aevi, V, Berolini 1928, 281/8-12). The quotation was then taken up in the canonical collections of Anselm of Lucca until the Decretum Gratiani (Decr. C. 16. q. 3 c. 17).

146 KAISER (1999) 85-86.
147 The episode is actually reported in a letter inserted by their editor among the spuriae (Epistolae Viennenses spuriae ep. 17, ed. GundLach, MGH Epp., III, [Epist. Merow. et Karol. aevi, I], 1892, 96/20-22). With the words "Nec debet ecclesia ullum damnum sustinere, si per sexaginta aut per septuaginta aut octoginta aut eo amplius annos incuria ... perdidit et amisit, quando innumeris pene annis illa, disponente spiritu Dei, usa fuerit«, Hadrian seems to consider, among others, the possibility of a centennial prescription; see CoNRAT (1891) 14 fn. 11 (toward the end).

148 Const. VIII c. 44: »Praesens constitutio ... iubet quidem sacratissimam ecclesiam Romanam centum anno- rum praescriptione solum in suis actionibus removeri. Nihil autem de ea latius exponemus, quia innovata est ab alia constitutione ...«; Const. CIC (CV) c. 366 »Iubemus, ut in negotiis quae antehac triginta annorum removebat exceptio, nunc venerabilibus ecclesiis ... quadraginta annorum protelatio conferebatur ... Haec autem constitutio et in praeteritis temporibus locum habet ...«; Const. CIX (CXX) c. 511: "Neque decennii, neque viginti vel triginta annorum praescriptio religiosis domibus opponatur, sed sola quadraginta annorum curricula ...«. 
ab alia constitutione), a >conservative (interpretation of the Nov. 9 was possible. Such an interpretation is precisely the one suggested both in the summaria capitum (especially those contained in the Wien and Leipzig codes) and in the text - purposely improved regarding this specific point - of the version of the Dictatum de consiliariis contained in the Berlin manuscript. ${ }^{149}$ It would be difficult to define this solution - so favourable to the popes' interests $^{\mathbf{1 5 0}}$ - as entirely groundless or simply naïve.

In summary, this particular interpretation of the imperial legislation appears to have been available to Gregory the Great in the late $6^{\text {th }}$ century, to the author of the summaria to the Epitome Iuliani (toward the beginning of the $7^{\text {th }}$ century) of the >Roman codes of Wien and Leipzig, (perhaps also) to Adrian I, after the mid- $8^{\text {th }}$ century and, finally, to John VIII, toward the end of the $8^{\text {th }}$ century. It seems to me all but impossible to deny that this interpretation - which certainly reveals a familiarity with Justinian law - was a product of the Roman environment. Finally, we have some solid and compelling arguments for positing the Roman origin of the Berlin manuscript or, more precisely, for its ancestor, in which both the summaria to the Epitome and the simproved text of the Dictatum de consiliariis were certainly present.

After this foray into the middle of the Carolingian era, it is now time to conclude. We have let our fantasy take flight in order to free our minds for other possibilities. Perhaps, in so doing, we were able to dream as Hermann Fitting once did. I hope - at least - to have offered you somnia pulchra et levia.

\section{Bibliography}

- Alberti, A. (1933), La `Glossa Torinese e le altre glosse del ms. D.III.13 della Biblioteca Nazionale di Torino, Torino

- Alberti, A. (1935), Ricerche su alcune Glosse alle Istituzioni e sulla »Summa Institutionum« pseudoirneriana, Messina

- Archi, G. G. (1981a), Scritti di diritto romano, III, Milano

- Archi, G. G. (1981b), Giustiniano e l'insegnamento del diritto, (1976), in: Archi (1981a) 1903-1942

- Archi, G. G. (1981c), Pragmatica sanctio pro petitione Vigilii, (1978), in: Archi (1981a) 1971-2010

- Archi, G. G. (cur.) (1985), Il mondo del diritto nell'epoca giustinianea. Caratteri e problematiche, Ravenna

- Astuti, G. (1953), Lezioni di storia del diritto italiano. Le fonti. Età romano-barbarica, Padova (rpr. with updating 1968)

- Becker, G. (1885), Catalogi bibliothecarum antiqui, 1, Bonn

- Bellettini, A. (2009), Glosse e testi aggiunti, in: Bellettini, A. et al. (ed.), Biografia di un manoscritto. L'Isidoro Malatestiano S.XXI.5, Roma, 35-56

- Bellomo, M. (1997), Società e istituzioni dal medioevo agli inizi dell'età moderna, Roma

- Belloni, A. (2008), Un'ipotesi per le Pandette fiorentine, in: Conte, E., V. Colli (ed.), Iuris Historia. Liber amicorum Gero Dolezalek, Berkeley, 1-16

- Bertolini, O. (1941), Roma di fronte a Bisanzio e ai Longobardi, [Storia di Roma, IX], Bologna

- Besta, E. (1923), Fonti: legislazione e scienza giuridica, in: Del Giudice, G. (ed.), Storia del diritto italiano, 1.1, Milano

- Beyerle, K. (1926), Lex Baiuvariorum, München

- Bischoff, B. (1984), Italienische Handschriften des neunten bis elften Jahrhunderts in frühmittelalterlichen Bibliotheken außerhalb Italiens, in: Questa, C., R. Raffaeli (ed.), Il libro e il testo. Atti del convegno internazionale. 20.-23.9.1982, Urbino, 169-194

- Bischoff, B. (1998), Katalog der festländischen Handschriften des neunten Jahrhunderts (mit Ausnahme der wisigotischen), I, Wiesbaden

149 KAISER (1999) 61-63 and 101-102.

150 The author of the so-called Lex Romana canonice compta (cc. 107 and 108) also seems to later accept the same solution. Later, the praescriptio C. annorum is also considered valid in ch. 140 of the Book of Tubing and in one of the appendices accompanying the Exceptiones legum Romanarum Petri of the manuscript of Prague (ch. 102); see Loschiavo (2007) 541-543. 
- Böhringer, Letha (ed.) (1992), Hinkmar von Reims, De divortio Lotharii regis et Theutbergae reginae, MGH, Conc., IV Suppl. 1, Hannover

- Calasso, F. (1954), Medioevo del diritto. I. Le fonti, Milano

- Cellurale, M. (2011), Romani y Gothi en Italia. La comunión de derecho en la república unida de Justiniano, in: Revista de Derecho Privado [Bogotá] 21, 21-40

- Chiodi, G. (2002), Roma e il diritto romano. Consulenze di giudici e strategie di avvocati dal X al XII secolo, in: Roma fra oriente e occidente [Settimane di studio del CISAM, XLIX], Spoleto, 1141-1254

- Ciaralli, A. (2002), Produzione manoscritta e trasmissione dei testi di natura giuridica fra XI e XII secolo: due esempi, in: Colli, V. (Hg.), Juristische Buchproduktion im Mittelalter, Frankfurt am Main, 71-103

- Ciaralli, A. (2012), Materiali per una storia del diritto in Italia meridionale. II. Tradizione, produzione e circolazione di testi di diritto romano giustinianeo in area longobardo-cassinese (secoli VIII-XII), in: Scripta 5, 43-63

- Ciaralli A., V. Longo (2001), Due contributi a un riesame della `Summa Perusinar (Perugia, Bibl. Cap. ms. 32), in: Scrittura e civiltà 25, 1-62

- Classen, P. (1983), Italien zwischen Byzanz und dem Frankenreich, in: Fleckenstein, J. (Hg.), Peter Classen, Ausgewählte Aufsätze, Sigmaringen, 85-115

- Colgrave, B., R. A. B. Minors (ed. and tr.) (1969), Bede's Ecclesiastical History of the English People, Oxford

- Collinet, P. (1925), Histoire de l'école de droit de Beyrouth, Paris

- Conrat (Cohn), M. (1884), Die Epitome Exactis regibus, Berlin (= Aalen 1965)

- Conrat (Cohn), M. (1891), Geschichte der Quellen und Literatur des römischen Rechts im frühen Mittelalter, Leipzig (= Aalen 1963)

- Conrat, M. (1898), La Somma delle Novelle De ordine ecclesiastico, in: Bullettino dell'Istituto di Diritto Romano 11, 7-22

- Conrat, M. (1907), Zur Kultur des Römischen Rechts im Westen des Römischen Reichs im vierten und fünften Jahrhundert nach Christi, in: Mélanges Fitting, Montpellier (= Aachen / Frankfurt a. M. 1969), 1, 289-320

- Cortese, E. (1993), Alle origini della scuola di Bologna, in: Rivista internazionale di Diritto Comune 4, 25-29 (rpr. in Cortese, E., Scritti, Spoleto 1999, II, 1113-1117)

- Cortese, E. (1995), Il diritto nella storia medievale. II. Il basso medioevo, Roma

- Cortese, E. (2001), Une carrière byzantine de Charlemagne, in: Tijdschrift voor Rechtsgeschiedenis 69, 1-10

- Cracco Ruggini, L. (1985), Giustiniano e la società italica, in: Archi (cur.) (1985) 173-207

- Crawford, M.H. (forthcoming), Paul the Deacon between Justinian and Bologna

- De Marini Avonzo, F. (2007), Sulle tracce della scuola di Roma nel VI secolo, in: Atti dell'Accademia Romanistica Costantiniana XVI, 31-40

- Di Paola, L. (2007), Insegnamento e diritto a Roma tra IV e VI secolo, in: Atti dell'Accademia Romanistica Costantiniana XVI, 85-101

- Dolezalek, G., A. Ciaralli (2010), Codicis Justiniani Epitome Beinecke and Summa Perusina (11 ${ }^{\text {th }}$ century), in: Ius romanum - ius commune - ius hodiernum. Studies in honour of Eltjo Schrage, Amsterdam, 75-100

- Ermini, F. (1938), La scuola in Roma nel VI secolo, (1934), in: Ermini, F., Medio evo latino. Studi e ricerche, Modena, 55-64

- Esders, S. (1997), Römische Rechtstradition und Merowingisches Königstum. Zum Rechtscharakter politischer Herrschaft in Burgund im 6. und 7. Jahrhundert, Göttingen

- Ewald, P., L. M. Hartmann (edd.) (1899), Gregorii I Registrum Epistolarum, II, in: MGH Epp., II, Berlin

- Falcone, G. (1996), I prestiti dalla Parafrasi di Teofilo nella cd. Glossa Torinese alle Istituzioni, in: SDHI 62, $255-286$

- Falkenhausen, V. von (1985), I rapporti dei ceti dirigenti romani con Costantinopoli dalla fine del V alla fine del VI secolo, in: Archi (cur.) (1985) 59-90

- Feenstra, R. (2011), Zur Faksimileedition der Kölner Institutionenhandschrift und zur Glossa Coloniensis, in: TRG 79, $521-532$

- Fingernagel, A. (1999), Die illuminierten lateinischen Handschriften süd-, west- und nordeuropäischer Provenienz der Staatsbibliothek zu Berlin PK 4.-12. Jahrhundert, Wiesbaden

- Fitting, H. (1870), Über die sogenannte Turiner Institutionenglosse und der sogenannte Brachylogus. Ein Beitrag zu der Geschichte des Römischen Rechtes vom sechsten bis elften Jahrhundert, Halle (= Amsterdam 1967)

- Frakes, R. M. (2011), Compiling the Collatio Legum Mosaicarum et Romanarum in Late Antiquity, Oxford

- Ganshof, F. L. (1969), Droit romain dans les Capitulaires et dans la collection d'Ansegise, in: IRMAe I, 2 b cc Bß, Milano

- Genzmer, E. (1934), Die Justinianische Kodifikation und die Glossatoren, in: Atti del Congresso internazionale di diritto Romano (Bologna e Roma, 17.-27.4.1933), I, Pavia, 345-430

- Goria, F. (1984), Romani, cittadinanza ed estensione della legislazione imperiale nelle costituzioni di Giustiniano, in: La nozione di "romano« tra cittadinanza e universalità, [Da Roma alla Terza Roma - Studi, II], Napoli, 277-342

- Goria, F. (2007), Le raccolte delle Novelle di Giustiniano e la Collezione greca delle 168 Novelle, in: Diritto e Storia 6, 1-11

- Gouron, A. (1993), Le manuscript 632 de la Sorbonne: a la convergence des droits savants en pays d'oc, (1985), in: Gouron, A., Droit et coutume en France aux XIIe et XIIIe siècles, [Variorum, CS 422], Aldershot

- Guillou, A. (1972), L'école dans l'Italie byzantine, in: La scuola nell'Occidente latino dell'alto medioevo [Settimane di studio del CISAM - XIX], Spoleto, I, 291-311

- Gundlach, W. (ed.) (1892), Epistolae Viennenses spuriae, in: MGH, Epp. III, Epistolae Merowingici et Karolini aevi, I, Berlin, 84-109

- Hänel, G. (ed.) (1873), Iuliani Epitome Latina Novellarum, Lipsiae

- KaISER, W. (1999), Zur hundertjährigen Verjährung zugunsten der römischen Kirche, in: ZRG kan. Abt. 85, 60-103

- KaIser, W. (2004), Die Epitome Iuliani. Beiträge zum römischen Recht im frühen Mittelalter und zum byzantinischen Rechtsunterricht, Frankfurt am Main 
- KaISER, W. (2008), Nachvergleichungen von Novellen- und Codexzitaten in einer frühmittelalterlichen Samlung mit Excerpten aus dem Register Gregors d. G. (Reg. 13,49[50]), in: ZRG rom. Abt. 125, 603-644

- Kaiser, W. (2012), Die Zweisprachigkeit reichsweiter Novellen unter Justinian, in: ZRG rom. Abt. 129, 392-474

- Kantorowicz, H.U. (1912), Max Conrat (Cohn), in: ZRG rom. Abt. 33, 417-483

- Kantorowicz, H. (with the collaboration of W. W. Buckland) (1938), Studies in the Glossators of the Roman Law, Cambridge (rpr. with addenda and corrigenda by P. Weimar, Aalen 1969)

- Krüger, P. (1868), Die Turiner Institutionenglosse, in: Zeitschrift für Rechtsgeschichte 7, 44-78

- Landau, P. (2004), Die Lex Baiuvariorum, München

- Landau, P. (2011), Jurisprudenz und Fälschung in Köln im 12. Jahrhundert. Die Kölner Institutionenglosse, in: Rivista internazionale di Diritto Comune 22, 9-33

- Lange, H. (1997), Römisches Recht im Mittelalter. I. Die Glossatoren, München

- Legendre, P. (1964), La pénétration du droit romain dans le droit canonique classique de Gratien a Innocent IV (1140-1254), Paris

- Liebs, D. (1987), Die Jurisprudenz im spätantiken Italien (260 - 640 n. Chr.), Berlin

- Liebs, D. (2000), Roman Law, in: Cameron, A. et al. (ed.), The Cambridge ancient history XIV: Late Antiquity: Empire and Successors, A. D. 425-600, Cambridge, 238-259

- Liebs, D. (2002), Römische Jurisprudenz in Gallien (2. bis 8. Jahrhundert), Berlin

- Liebs, D. (2006), Review of Kaiser, Epitome Iuliani, in: ZRG rom Abt. 123, pp. 400-412 Liebs, D. (2008), Juristenausbildung in der Spätantike, in: Baldus, CH. et al. (ed.), Juristenausbildung in Europa zwischen Tradition und Reform, Tübingen, 31-45

- Liebs, D. (in print), The Scholia Veronensia on the Justinian Code and the Pistoia Codex Gloss: Roman Jurisprudence in Early Medieval Italy

- Lokin, J. H. A. et al. (2010), Theophili antecessoris Paraphrasis Institutionum, Groningen (with an English translation - not yet published - by A. F. Murison)

- Loschiavo, L. (1996), Summa Codicis Berolinensis. Studio ed edizione di una »composizione a mosaico«, Frankfurt am Main

- Loschiavo, L. (2006), La Legge che Dio trasmise a Mosè. Fortuna medievale di un'operetta volgare, in: Condorelli, O., M. Bellomo (cur.), Proceedings of the XI. International Congress of Medieval Canon Law, [Monumenta Iuris Canonici, ser. C: Subsidia, 12], Città del Vaticano, 85-102

- Loschiavo, L. (2007), Intorno al privilegio della spraescriptio centum annorum‘, in: Itinerari giuridici. Per il quarantennale della Facoltà giuridica dell'Abruzzo, Milano, 533-553

- Loschiavo, L. (2010), Il >codex graecus`e le origini del Liber Authenticorum, in: ZRG rom. Abt. 127, 55-171

- Macino, F. (2008), Sulle tracce delle Istituzioni di Giustiniano nell'alto medioevo. I manoscritti dal VI al XII secolo, Città del Vaticano

- Manthe, U. (2011), Dubletten im Text der Collatio als Spuren der Redaktionstätigkeit, in: Muscheler, K. (Hg.), Römische Jurisprudenz - Dogmatik, Überlieferung, Rezeption. Festschrift für D. Liebs, Berlin, 395-412

- Marrou, H.-I. (1931), Autour de la bibliothèque du pape Agapit, in: Mélanges de l'École française a Rome 48 (now in Marrou, H.-I., Christiana tempora, Roma 1978)

- Martindale, R. (1992), The Prosopography of the later Roman Empire, 3 A-B, Cambridge

- Mikat, P. (1994), Die Inzestgesetzgebung der merowingisch-fränkischen Konzilien (511-626/27), Paderborn

- Mor, C. G. (1977), Il Digesto nell'età preirneriana e la formazione della »vulgata«, (1934), rpr. in: Mor, C. G., Scritti di storia giuridica altomedievale, Pisa, 83-214

- Moschetri, G. (1953), I frammenti veronesi del secolo IX delle Istituzioni di Giustiniano, in: Atti del Congresso internazionale di Diritto romano e di storia del diritto - Verona 27./29.9.1948, I, Milano, 439-509

- Moschetti, G. (2006), Frammenti veronesi del secolo IX delle Istituzioni di Giustiniano, Roma

- Nicolaj, G. (1991), Cultura e prassi di notai preirneriani. Alle origini del rinascimento giuridico, Milano

- NicolaJ, G. (2001), Ambiti di copia e copisti giuridici in Italia (secoli V-XII in.), in: BirocchI, I. et al. (cur.), A Ennio Cortese, Roma, II, 478-496

- Nicolaj, G. (2005), Documenti e Libri legales a Ravenna: rilettura di un mosaico leggendario, in: Ravenna da capitale imperiale a capitale esarcale, Spoleto, 761-799

- Odofredus, Lectura super Digesto veteri, ed. Lugduni 1550 [= Bologna 1967]

- Odofredus, In novem posteriores libros Infortiati, ed. Lugduni 1550 [= Bologna 1968]

- Patetta, F. (1900), Adnotationes Codicum domini Iustiniani (Summa Perusina), in: Bullettino dell'Istituto di Dritto Romano 12 (rpr., with an introduction of S. Caprioli, Firenze 2008)

- Patetta, F. (1967a), Studi sulle fonti giuridichemedievali, Torino

- Patetta, F. (1967b), Contributi alla storia del diritto romano nel medio evo [1891], II. Nota sopra alcuni mss. delle Istituzioni di Giustiniano, in: Patetta (1967a) 41-120

- Patetta, F. (1967c), Il Breviario Alariciano in Italia [1891], in: PAtetta (1967a) 601-643

- Pertz, Georg Heinrich (ed.) (1826), Chronicon Moissiacense, in: MGH, SS, I, Annales et chronica aevi Carolini, Berlin, 280-313

- Pescani, P. (1966), Pragmatica sanctio pro petitione Vigilii, in: Novissimo digesto italiano, XIII, Torino, 553-554

- Petrucci, A. (1972), Libro, scrittura e scuola, in: La scuola nell'Occidente latino dell'alto medioevo [Settimane di studio del CISAM - XIX], Spoleto, I, 313-337

- Pieler, P. (1978), Byzantinische Rechtsliteratur, in: Handbuch der Altertumswissenschaft. Abt. 12, Byzantinisches Handbuch. 5. Teil - Hunger, H. (Hg.), Die hochsprachliche profane Literatur der Byzantiner, München, 341-480

- Pringsheim, F. (1921), Beryt und Bologna, in: Festschrift Otto Lenel, Leipzig (= Frankfurt am Main 1987), 204-285 
- Radding, Ch. M., A. Ciaralli (2007), The Corpus Iuris Civilis in the Middle Ages. Manuscripts and Transmission from the Sixth Century to the Juristic Revival, Leiden

- Reynolds, R. E. (1990), The south-Italian Canon Law Collection in Five Books and its Derivatives: new evidence on its origins, diffusion, and use, in: Medieval Studies 52, 278-295 (rpr. in Reynolds, R. E., Law and Liturgy in the Latin Church. $5^{\text {th }}-12^{\text {th }}$ Centuries, [Variorum, CS 457], XIV, Aldershot 1994)

- Richards, J. (1980), Consul of God. The Life and Times of Gregory the Great, London

- Riché, P. (1979), Les écoles et l'enseignement dans l'Occident chrétien de la fin du V $\mathrm{e}^{\mathrm{e}}$ siècle au milieu du XI $\mathrm{e}^{\mathrm{e}}$ siècle, Paris

- Röhle, R. (1968), Das Berliner Institutionen- und Digestenfragment Ms. lat. fol. 269, in: Bullettino dell'Istituto di Diritto Romano 71, 128-173

- SANTini, G. (1994), Il sapere giuridico occidentale e la sua trasmissione dal VI all'XI secolo, in: Rivista di storia del diritto italiano 67, 91-204

- Savigny, F. C. von (1834), Geschichte des römischen Rechts im Mittelalter, 2nd ed., Heidelberg (= 1956)

- Savigny, F. C. von (1857), Storia del diritto romano nel Medio evo, III, 2a ed. Torino

- Scheltema, H.J. (1970), L'enseignement de droit des antecécesseurs, Leiden (also in: Scheltema, H.J., Opera minora, Groningen 2004, 58-110)

- Schramm, P. E. (1929), Studien zu frühmittelalterlichen Aufzeichnungen über Staat und Verfassung, in: ZRG germ. Abt. 49, $167-232$

- Schramm, P. E. (1992), Kaiser, Rom und Renovatio. Studien zur Geschichte des römischen Erneuerungsgedankens vom Ende des Karolingischen Reiches bis zum Investiturstreit, Darmstadt

- Schulz, F. (1946), The Manuscripts of the Collatio Legum Mosaicarum et Romanarum, in: Symbolae ad jus et historiam antiquitatis pertinentes J. Ch. Van Oven dedicatae, Leiden, 313-332

- Schulz, F. (1953), History of Roman Legal Science, $2^{\text {nd }}$ ed., Oxford

- Siems, H. (1992), Handel und Wucher im Spiegel frühmittelalterlicher Rechtsquellen, Hannover

- Stein, E. (1939), La disparition du Sénat de Rome à la fin du VIe siécle, now in: STEIN, E., Opera minora selecta, Amsterdam 1968, 308-322

- Supino Martini, P. (1987), Roma e l'area grafica romanesca, Alessandria

- Thaner, Friedrich (ed.) 1891, Liber canonum contra Henricum IV, in: MGH, Libelli de lite Imperatorum et Pontificum, I, Berlin, 471-516

- TJÄDER, J.-O. (1985), Alcune osservazioni sulla prassi documentaria a Ravenna nel VI secolo, in: ArCHI, G. G. (cur.) (1985) 23-42

- van der Wal, N. (1985), Die Paràtitla zur Epitome Iuliani, in: Subseciva Groningana 2, 93-137

- Volterra, E. (1957), Appunti sulle scuole postclassiche occidentali, in: Annali di Storia del Diritto 1, 51-65

- Weigand, R. (1988), Fragmente des römischen Rechts in der Universitätsbibliothek Würzburg, in: ZRG rom. Abt. 105, $784-788$ 